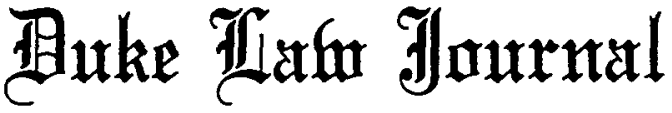

\begin{tabular}{lll}
\hline VOLUME 1981 & SEPTEMBER & NUMBER 4 \\
\hline
\end{tabular}

\section{LIMITATIONS ON THE OBLIGATION OF GOOD FAITH}

\author{
Clayton P. Gillette*
}

Scholarship addressed to the good faith provisions ${ }^{1}$ of the Uniform Commercial Code primarily discusses the intractable difficulty of defining the scope of the obligation to perform and enforce one's contract in good faith. ${ }^{2}$ Many scholars advocate an expansive interpretation of good faith, currently defined in the Code as "honesty in fact in the conduct or transaction concerned." 3 One writer proposes that good

* Associate Professor of Law, Boston University School of Law. B.A. 1972, Amherst College; J.D. 1975, University of Michigan.

Numerous persons have provided helpful readings or discussions of previous drafts of this article. Particular thanks are due to James Henderson, John Hetherington, Douglas Leslie, Mark Pettit, David Phillips, Robert Scott, Richard Speidel, and William Vukowich.

1. The good faith obligation discussed in this article is set forth in section 1-203 of the Uniform Commercial Code: "Every contract or duty within this Act imposes an obligation of good faith in its performance or enforcennent." U.C.C. § 1-203. "Good faith" is defined in UCC section 1-201(19) to inean "honesty in fact in the conduct or transaction concerned." Article 2, however, contains a separate definition of good faith to be employed when that Article expressly imposes a good faith requirement. Section 2-103(1)(b) provides: " 'Good faith' in the case of a merchant means honesty in fact and the observance of reasonable commercial standards of fair dealing in the trade." U.C.C. \$ 2-103(1)(b). See note 34 infra.

2. The most comprehensive study is Summers, "Good Faith" in General Contract Law and the Sales Provisions of the Uniform Commercial Code, 54 VA. L. REv. 195 (1968), in which the author recognizes the difficulty of providing specific content to the Code provision and advocates its use to exclude certain conduct from acceptable commercial behavior. Summers discusses potential remedies for bad faith conduct, but does not discuss the feasibility or internal consistency of such remedies. Id. 252-62. Other treatments of the good faith obligation are found in Farnsworth, Good Faith Performance and Commercial Reasonableness Under the Uniform Commercial Code, 30 U. Chi. L. Rev. 666 (1963), and Powell, Good Faith in Contracts, 9 Current Legal Prob. 16 (1956). Application of the obligation to specific problems is discussed in Dugan, Good Faith and the Enforceability of Standardized Terms, 22 WM. \& MARY L. REv. 1 (1980); Hillman, Policing Contract Modifications Under the U.C.C.: Good Faith and the Doctrine of Economic Duress, 64 IowA L. Rev. 849 (1979); Holmes, A Contextual Study of Commercial Good Faith: GoodFaith Disclosure in Contract Formation, 39 U. PITr. L. REv. 381 (1978).

3. U.C.C. \& 1-201(19). See note 1 supra. 
faith be defined to require commercial actors to forbear from declaring technical breaches. ${ }^{4}$ Another proposcs that good faith requires disclosure of advantageous information withheld to attain a superior bargain rather than to deceive or cheat. ${ }^{5}$ At least one court has adopted an expansive interpretation of good faith to prevent commercial actors froin taking advantage of changed circumstances that adversely affect other contracting parties. ${ }^{6}$ Another court has been asked to rule that a seller's denial of a buyer's request for niodification of a contract constitutes bad faith conduct. ${ }^{7}$ In these instances the obligation becomes less of a duty not to create undue risks to others and inore of a duty to assist others confronted with risks not created by the obligor.

An expansive good faith obligation is appealing. It suggests that commercial law be guided by ethical considerations such as promisekeeping, benevolence, and equality of interested parties in addition to traditional prohibitions of fraud or deceit. Moreover, the phrase "good faith" connotes altruisnt and creative remedies against selfishness or egotisnn. ${ }^{8}$ Nevertheless, this article questions the propriety of an expansive interpretation of the good faith obligation. The article concludes that, notwithstanding a drafting history that partially supports the use of a good faith obligation to transforin altruistic behavior into a legal duty, and subsequent scholarly development of that interpretation, courts justifiably have restricted the scope of the obligation. This conclusion is predicated on arguments that an expansive obligation extends the responsibilities of commercial actors beyond bargained-for risk allocations, subjects bargains to inconsistent and uncertain enforceinent, and does not produce offsetting benefits in commercial conduct.

Implicit in these conclusions is the belief that the nebulous scope of good faith may be clarified by focusing on the availability of an appropriate remedy within each proffered definition. To define an obligation in teruns of the remedies available for its violation niay appear to go about the rights-reniedies process backwards. Once a right is determined to exist, one may argue, judicial latitude inust be permitted in

4. See Summers, supra note 2, at 234-35.

5. See Holmes, supra note 2, at 435-49. Lord Mansfield imposed an obligation of good faith that required disclosure of unusual facts known to only one contracting party. See P. ATIYAH, THe Rise AND Fall of Freedom of Contract 168-69 (1979).

6. Baker v. Ratzlaff, 1 Kan. App. 2d 285, 288, 564 P.2d 153, 156 (1977).

7. Missouri Pub. Serv. Co. v. Peabody Coal Co., 583 S.W.2d 721 (Mo. App.), cert. denied, 444 U.S. 865 (1979).

8. See Kennedy, Form and Substance in Private Law Adjudication, 89 HARv. L. Rev. 1685 (1976). 
order to structure a remedy appropriate to the situation. ${ }^{9}$ The Code, however, is a tool for busmessmen and their attorneys to predict the legal consequences of voluntary transactions. ${ }^{10}$ Reahzation of that goal requires precision of definition and certamty of the effects of performance and nonperformance. Perhaps predictability sometimes can be achieved by relatively vague standards. ${ }^{11}$ Nevertheless, vagueness of the good faith language raises suspicions about the scope and force of the obligation. Investigation into potential remedies may reveal whetlier the consequences of violatimg the good faith obligation are sufficiently clear to state that the obligation provides the predictability promised by the Code.

The existence of a certain remedy for a violation of a statutory obligation of good faith takes on additional significance in light of Professor Powell's observation that the success of such a provision depends on its independent force. ${ }^{12} \mathrm{He}$ explains the degree of vitality of similar provisions in European legal systems as a function of the remedies provided for their violation. ${ }^{13}$ Responding nearly a decade ago to Powell's work, Professors Kessler and Gilmore were uncertain whether the good faith obligation would become a substantial, enforceable requirement of commercial behavior or little more than statutory surplusage. ${ }^{14}$ The conclusions of this article suggest that, thus far, courts largely have resisted the entreaties of commentators to invigorate the good faith obligation. The question is whether that outcome is desirable or mevitable. ${ }^{15}$

\section{The "Original Intent"}

Measurement of the proper scope of the good faith obligation requires understanding its intended function in ordering commercial behavior. The decision to define "good faith" in the Code to include ouly "honesty im fact in the conduct or transaction concerned" is not decisive of the drafters' imtent. "Honesty" may be interpreted to preclude

9. Summers, for instance, contends that "case law reform" is necessary to provide remedies for bad faith if tort or contract remedies fail to address the actor's conduct. Summers, supra note 2 , at 252-53.

10. See U.C.C. § 1-102; W. Twining, KarL LLEWELLYN AND THE REALIST MOveMENT 304 (1973).

11. See Kennedy, supra note 8, at 1704-05.

12. See Powell, supra note 2, at 31.

13. See id. 32-35.

14. See F. Kessler \& G. GILMORE, Contracts 912 (1970).

15. Reaching some consensus on the scope of the Code obligation of good faith gains importance in light of the inclusion of a similar good faith obligation in the most recent tentative draft of the RestATEMENT (SECOND) OF CONTRACTS $\S 231$ (Tent. Draft No. 8, 1973). That section adds to the obligation a requirement of "fair dealing." 
only active misrepresentations or, more broadly, to prohibit obligors from taking unfair advantage of an obligee's weak position, althouglı the obligor bears no responsibility for the creation of that position. In the absence of a clear concept of "honesty," one can envision a number of functions of the good faith obligation that the drafters of the Code might have contemplated. Possible functions include: to impose liability only for lying, deceit, or fraud; ${ }^{16}$ to create a gap filler that permits judges to impose liability for condemnable commercial behavior that does not fit within traditional categories of actionable conduct; ${ }^{17}$ to impose liability on commercial actors who fail to satisfy their voluntarily assumed obligations, consistent with the ethical imperative to keep one's promise (even if that requires personal sacrifice); ${ }^{18}$ and to encourage commercial actors to behave in the most reasonable manner under the circumstances, considering the interests of other parties. ${ }^{19}$

Each objective proscribes a different range of conduct and requires a different sanction. The first objective, for instance, condemns dishonesty only in its most restricted sense, while the fourth objective condemns numerous forns of commercial conduct that cannot be reaclied by even a broad definition of dislionesty, such as negligent failure to disclose infornnation or admitted-and therefore "honest"-attempts to take advantage of other parties. Eacli interpretation assumes a model of proper commercial behavior and purports to penalize noncompliance with that model. Inability to remedy a violation of the obligation in a manner consistent with the rest of the Code and amenable to our notion of commercial remedies would go far to undermine any of these objectives. Furthermore, if we are unable to determine the intended interpretation of the good faith obligation and if we also assume that the drafters did not imtend to enact an imternally imconsistent scheme of commercial law, the unavailability of a remedy necessary to accom-

16. This interpretation follows from a literal reading of section 1-201(19). See Summers, supra note 2, at 213-15.

17. This gap-filler function appears to be that intended by the UCC's good faith obligation as discussed in Danzig, A Comment on the Jurisprudence of the Uniform Commercial Code, 27 STAN. L. REv. 621, 631 (1975). It is also consistent with the "excluder" analysis in Summers, supra note 2. Farnsworth perceives the function of good faith as permitting judges "[to imply] terms in the agreement." Farnsworth, supra note 2, at 670.

18. On the relationship between commercial law and the sanctity of promises, see C. FrIED, Contract as Promise (1981); Cohen, The Basis of Contract, 46 Harv. L. Rev. 553, 571-75 (1933).

19. Of course, these concepts are not inutually exclusive. For example, Summers includes the gap-filler function in a family of doctrines that "supplement, limit and qualify specific legal rules." Summers, supra note 2, at 198. The supplementation process, however, takes place against a inoral background that Summers implies is inherent in proper commercial conduct. See id. 198, 214. 
phish any of these objectives would help us determine which objective actually was intended.

The drafting history of the Code does not indicate conclusively which interpretation of the good faith provision was intended. At an early stage of the process, the drafters defined the obligation of good faith to include both honesty in fact and observance of reasonable coinmercial standards in an actor's business or trade. ${ }^{20}$ The Comment to section 1-203 explained the obligation in terms of "commercial decencies" and envisioned commercial practice as a cooperative, rather than an adversarial, process. ${ }^{21}$ The Comment implied that a contract creates a relationship that requires each party to act with due regard for the interests of both parties. If this Comment had survived, an expansive interpretation of the obligation could be defended on the ground that among the "decencies" observed by parties to a contract is the recognition of affirmative duties towards one another that would not otherwise exist. ${ }^{22}$ The good faith obligation thus appeared to impose duties that transcend the responsibilities of all persons not to lie or cheat. The latter conduct was and is addressed by separate Code sections and requires no novel obligation to vindicate the rights of the defrauded and cheated. "Commercial decencies" appear to exact an additional and extraordinary degree of concern for others. Subsequently, however, the Section on Corporation, Banking and Business Law of the American Bar Association advocated limiting the definition of good faith to the absence of dishonesty, trickery, deceit, or improper purpose. ${ }^{23}$ The ABA Section's Committee on the Proposed Commercial Code explained its proposal as a means of avoiding inflexibility in commercial

20. Section 1-201(16) of the May 1949 Draft of the Uniform Commercial Code defined good faith as follows: "'Good faith' means honesty im fact in the conduct or transaction concerned. Good faith includes good faith toward all prior parties and observance by a person of the reasonable commercial standards of any business or trade in which he is engaged." U.C.C. $\$ 1-201(16)$ (May 1949 Draft). The drafting history is considered in some depth in Summers, supra note 2. The discussion here is an attempt to build on and point out differences with Summers's interpretation.

21. Perhaps the most significant sentence in the Comment to section 1-203 was: "This Act adopts the primciples of those cases which see a commercial contract not as an 'arm's-length' adversary venture, but as a venture of material interest, when successful, and as involving due regard for commercial decencies when the expected favorable outcome fails." U.C.C. \& 1-203, Comment (May 1949 Draft).

22. The obvious analogue is to the principle in tort law that, notwithstanding the absence of a general duty to save another person from harm not caused by the actor, that actor is obligated to attempt a rescue if there is a special relationship between the parties, including certain familial and business relationships. See W. Prosser, HandBook of THE LAW OF TORTS 340-43 (4th ed. 1971).

23. ABa Section of Corporation, Banking and Business law, Report of the Committee on the Proposed COMmercial Code, reprinted in Malcolm, The Proposed Commercial Code, 6 Bus. LAw. 113, 128 (1951). 
custoins by ensuring that practices existing at a given moinent did not becoine a perpetual standard. ${ }^{24}$ It appears, however, that the Committee was responding with equal fervor to those meinbers of the bar who considered section 1-203 an affront to the good name of commercial interests. ${ }^{25}$ In response, the 1952 version of the Code limited the definition of "good faith" to its present form of "honesty in fact."26

A less altruistic motivation for limiting the obligation is suggested by Grant Gilmore's account of the drafting history of the Code. ${ }^{27}$ Gilnore indicates that practicing attorneys who participated in drafting the Code becaine more influential as the document reached its final stages. ${ }^{28}$ The practitioners allegedly used their influence to restrict opportunities for courts to create innovative commercial obligations. The Code, instead, was to employ language that would "control the courts and compel decision." 29 This version of the drafting process suggests that the limitation in the current definition of good faith ${ }^{30}$ was intentional-a clear rejection of "commercial decencies" as an unnecessarily broad, moralistic imperative. Instead, only the deliberate lie, the inalicious deception, was outlawed. The Comment incorporating "commercial decencies" was replaced with a vague paraphrase of the language of section 1-203. ${ }^{31}$ If the drafters intended to emasculate the obligation, Summers's contention that "[i]f an obligation of good faitl is to do its job, it must be open-ended"32 misses the inark. The final version of the Comment deliberately defines the job of good faith in a closed-ended manner. Only in the Article 2 sections that specifically refer to good faith, thereby incorporating the section $2-103(1)$ (b) definition, ${ }^{33}$ is there

24. Id., reprinted in 6 Bus. LAW. 128 (1951). The Report concluded that if its recommendations were adopted, "[s]ection 1-203 might be eliminated as unnecessary." Id, reprinted in 6 Bus. LAw. 128 (1951).

25. See id, reprinted in 6 Bus. LAw. 128 (1951). Malcolm reported that members of the ABA Section adopted on May 16, 1950, a resolution that noted objections "to the point of view appearing or reffected in some sections, and more frequently in the Comments, to the effect that business interests are rapacious and that it is necessary to protect other members of the public from oppression from such interests." Malcolm, The Proposed Commercial Code, 6 Bus. LAw. 113, 115 (1951).

26. See U.C.C. \& 1-201(19) (Official Draft 1952).

27. G. GiLMORE, THE Ages of AMERICAN Law 83-86 (1977).

28. Id. 85.

29. Id.

30. See note 1 supra.

31. In the 1952 Official Draft of the Code, language of "commercial decencies" had been eliminated from the Comment to section 1-203. Instead, the Comment assumed its present form, which provides few standards for defining good faith and confuses the issue by citing to Article 2 situations which presumably would be governed by the broader section 2-103(1)(b) definition of good faith. See U.C.C. \& 1-203, Comment (Official Draft 1952).

32. Summers, supra note 2, at 215.

33. See note 1 supra. 
a broader obligation for merchants to comply with reasonable commercial standards of fair dealing as well as honesty. ${ }^{34}$

While there may be equivocal support in the drafting history for a hiteral and narrow reading of the "honesty in fact" definition of good faith, the imquiry must not end there. Even after acceptance of the unembellished "honesty in fact" definition, the Code's drafters and sponsors did not define the phrase with unanimity. Professor Edwin Patterson explained the function of section 1-203 to the New York Law Revision Commission in terms more consistent with the "gap filler" objective ${ }^{35}$ than with the narrow literal wording of the provision. ${ }^{36}$ To him, the provision transcended the proscription of dishonesty and included requirements of "generosity," "co-operation," and mitigation of the results of "hard luck." 37 The alteration of the Comment to section 1-203 did not change Professor Patterson's understanding of the provision's function. In a brief review of the legislative history of the Code, ${ }^{38}$ then-Professor Braucher recalled that the extension of the good faith obligation to enforcement as well as performance of the contract was motivated by a desire to protect a defaulting buyer against a seller who fails to mitigate damages. ${ }^{39}$ Because failure to mitigate is only a failure to assist, rather than dishonesty or deceit, it is difficult to reconcile Braucher's recollection with a narrow construction of "honesty in fact." Students of the philosophy underlying the Code also seeln to favor a less restrictive interpretation of the good faith obligation as most consistent with Code jurisprudence. ${ }^{40}$ At times, this expansive interpretation is recognized explicitly, but often it is implicit in the perceived role of the good faith obligation. For instance, in a recent article on the common law obhgation of good faith, ${ }^{41}$ Professor Burton argues that a commercial actor exhibits bad faith when he'acts to recapture opportunities forgone at earlier stages of the contracting process. On

34. There may be some argument that the broader definition of section 2-103(1)(b) pervades all of Article 2. See Summers, supra note 2, at 212. Most commentators have concluded, however, that the definition applies only to those sections of Article 2 that expressly mention good faith. See id. 212-13. Dugan, supra note 2, at 11-12.

35. See text accompanying note 17 supra.

36. I Report OF THE NEW YORK LAw Revision CoMmission, Study OF THE UNiform COMMERCIAL CODE 310-315 (1955).

37. Id. 311. With this view, Professor Patterson suggested that the provision function as a tabula in naufragio, a position supported by preexisting New York case law.

38. Braucher, The Legislative History of the Uniform Commercial Code, 58 Colum. L. REv. 798 (1958).

39. Id. 813.

40. See Danzig, supra note 17, at 634; Hawkland, Uniform Commercial "Code" Methodology, 1962 U. ILL. L.F. 291, 305.

41. Burton, Breach of Contract and the Common Law Duty to Perform in Good Faith, 94 HARV. L. REV. 369 (1980). 
the assumption that such action necessarily harms the other party, ${ }^{42}$ Burton's analysis requires a commercial actor to abstain froin avoiding the consequences of changed circumstances not only when he has assumed the risk of such changes, but also when he should have assuined that risk. ${ }^{43}$ Implicit in this rationale is the notion that good faith requires diligent concern for the other party's position, notwithstanding an absence in the contract of an allocation of the risks that create that concern.

Even if the drafters had concurred in an interpretation of good faith, we would not be very far along the road to discovering its "intended" interpretation. The drafters did not adopt the Code; legislatures did, and we have virtually no evidence of what the legislatures thought of the obligation. ${ }^{44}$ Even if some drafters believed "lionesty in fact" included affirmative obligations to render aid, legislators easily might have thought otherwise. Furthernore, there is no reason to believe that the understanding anong the legislators of any one legislature was internally consistent or consistent with the understanding of the legislature of another jurisdiction.

\section{The Judicial Response}

Given the equivocal historical foundation for interpretation of the good faith obligation as a means to transform commercial altruism into a legal duty, it is useful to inquire how the courts have responded to the provision. If courts lrave applied the obligation expansively, analysis of the cases should test the assuinption that an informal standard is susceptible to certainty of definition and consequence. Though less can be concluded froin a determination that the courts have avoided expansive interpretations, this avoidance may suggest eitler judicial unwillingness or inability to develop the boundaries of "commercial decencies."

Perusal of the cases initially suggests judicial rejection of the literal restriction of honesty in fact. ${ }^{45}$ A closer reading, however, reveals that although conduct inconsistent with good faith has been discovered in

42. Id. 387.

43. See id. $390-91$ (the identity of foregone opportunities is based on an objective standard).

44. Various state statutes contain commentary and annotations on Uniform Commercial Code provisions. See, e.g., N.Y. U.C.C. \$\$ 1-101 to 10-105. (McKinney 1964). These annotations, however, have been prepared by practitioners or academics in the state and do not appear to have evolved froin any legislative report. For background on the traditional difficulties of discerning legislative inotivation, see generally Symposium on Legislative Motivation, 15 SAN DiEGo L. REv. 925 (1978).

45. See, e.g., Standard Alliance Indus., Inc. v. Black Clawson Co., 587 F.2d 813, 827-28 (6th Cir. 1978), cert. denied, 441 U.S. 923 (1979) (good faith requires the buyer to notify the seller of a continuing breach; no allegation of deceit or fraud). 
circumstances that might be considered void of dishonesty in the narrow sense, the legal consequences of that discovery are limited. Little evidence exists that suggests the courts have invested the obligation with a life of its own by permitting independent redress against bad faith conduct. Remedies in cases that cite the good faith obligation rarely seem directed at violation of that obligation. ${ }^{46}$ If bad faith were an independent basis of legal liability, courts slould find a breach of contract in circuinstances that, but for bad faith, would not justify the finding of a breach. Alternatively, a nore liberal damage award to the victim of a bad faith breacli might be observed. The cases in which conduct violative of section 1-203 is discovered simply grant redress that would have been available in the same fact situation notwithstanding the absence of a good faith obligation. ${ }^{47}$

46. In Oloffson v. Coomer, 11 Ill. App. 3d 918, 296 N.E.2d 871 (1973), the court held that a dealer could not claim that his failure to cover a contract after an anticipatory repudiation was permissible under the "commercially reasonable time" doctrine of section 2-610. Id. at 922, 296 N.E.2d at 874. The court found that the dealer had unequivocal notice of nonperformance and that his failure to disclose a usage of trade concerning contract cancellation constituted bad faith. Id. at 922-23, 296 N.E.2d at 874-75. It is unclear whether the bad faith argument constituted an independent source of liability, see Liebson, Anticipatory Repudiation and Buyer's Damages-A Look into How the UCC Has Changed the Common Law, 7 U.C.C.L.J. 272, 279 (1975), or was part of the rationale for finding passage of a reasonable time, see Note, Failure to Cover and Time to Measure Buyer's Damages, 49 U. CoLo. L. Rev. 233, 243 (1978). But see Baker v. Ratzlaff, 1 Kan. App. 2d 285, 564 P.2d 153 (1977).

47. Indeed, one court, apprised of the possibility of creating an independent cause of action for bad faith conduct, expressly refused to do so. In Chandler v. Hunter, 340 So. $2 \mathrm{~d} 818$ (Ala. Civ. App. 1976), plaintiff brought an action for damages suffered because of the disintegration of a mobile home purchased from the defendants. In addition to claims based on misrepresentation and implied warranty, plaintiff alleged a breach of a duty on the part of the defendants to exercise good faith in their dealings with her. Though the appeals court reunanded the case for trial on the fraud and warranty allegations, it held that a claimed breach of the obligation imposed by section 1-203 did not state a claim for which relief could be granted. The court concluded with the admoIntion that nothing in the Code indicated the good faith requirenent "was intended to be remedial rather than directive." Id. at 821.

It seems clear that the Chandler court believed that section 1-203 applied to the situation before it, even though it did not believe that the provision permitted any remedial assistance to a victim of bad faith; but there is some question of whether the defendants owed the plaintiff a duty of good faith at all. The alleged breacls of the obligation comprised representations that appear to have been made in the course of negotiations with the purcliaser, i.e., during the pre-contract stage. Section 1-203, on which plaintiff relied, imposes an obligation of good faith in the performance or enforcement of a contract. The obligation to negotiate im good faith is conspicuously absent. It does not appear that this omission is the result of oversight. In his analysis for the New York State Law Revision Commission, Professor Patterson noted:

Good faith in the nnaking of a commercial contract is not required by Section I-203 and is not required by New York case law. That is, one party to such a contract is not required to disclose to the other a inaterial fact relating to the prudence or value of the bargain, even though the one who knows this fact also is aware that the other party does not know it, and would not make the contract if he did.

Report OF THE New YoRK LAW Revision Commission, supra note 36, at 315. See also Cargill, Inc. v. Kavanaugh, 228 N.W.2d 133, I40 (N.D. 1975). As Professor Summers has pointed out, 
In one series of cases, courts have used the good faith clause to prevent obligors from altering situations that they lulled obligees into believing would remain constant. In such cases, the affirmative conduct of the obligor may not rise to the level of an actionable misrepresentation, but it appears to reflect an effort to stay within the letter of the contract while avoiding its spirit. Thus, an insurance company that had waived its right under its policy to subrogation against an insured could not revive the subrogation right by making a clami under an assignment. ${ }^{48}$ Similarly, a corporation whose principals also were partners in a partnership that had entered into a negative pledge agreeinent with the government was not entitled to priority over the government in assets subject to the negative pledge, although the corporation had perfected its interest first. ${ }^{49}$ These cases are similar to misrepresentation or dishonesty cases, however, in that the obligor's conduct is responsible for the weakened position of the obligee. These cases are unlike situations in which obligors fail to assist or take advantage of a weakened party whose position is not attributable to the obligor's conduct.

Outside of these few cases in which good faith has been used to prohibit obligors from affirmatively altering circnmstances that they imduced obhigees to believe would remain constant, the good faith obligation appears to play only a supporting role. In the typical case in which section 1-203 is invoked, the court imposes hability on a bad faith actor on the basis of some alternate substantive cause of action that appears to form the primary ratio decidendi of the court's holding. The absence of good faith is relegated to little more than a inakeweight to support the alternative cause of action, and often appears, by its superficial treatment, to be an afterthought.

In re Davidoff ${ }^{\text {so }}$ is illustrative of such cases. The petitioner bank sought to reclaim dental equipment im which it had been granted a security interest prior to the debtor's bankruptcy. The bank had filed a financing statement with the county clerk's office but had failed to make the duplicate filing with the Secretary of State necessary to perfect a security interest in New York. Subsequently, the debtor bor-

however, if good faith is limited to the requirement of honesty in fact, then the result of requiring good faith negotiation also can be achieved through invocation of general principles of fraud and deceit under section 1-103. The Tentative Draft of the Restatement (Second) of Contracts explicitly rejects application of the good faith obligation to the pre-contract stage. Instead, the Restatement leaves negotiators to their own devices and the common law remedy for fraud. See Restatement (Second) of Contracts $\$ 231$, Comment c (Tent. Draft No. 8, 1973).

48. Integrity Ins. Co. v. Davis, 116 N.J. Super. 417, 282 A.2d 452 (1971).

49. Thompson v. United States, 408 F.2d 1075, 1084-85 (8th Cir. 1969).

50. 351 F. Supp. 440 (S.D.N.Y. 1972). 
termined shortly after taking possession that the engine was not performing as warranted by the seller and manufacturer. Nevertheless, the purchaser delayed notifying the seller of the nonconformity and thereafter refused to let him make repairs. Six months after he ceased using the engine, the purchaser returned the engine and demanded rescission. The court denied the purchaser's claim on the theory that the delay in informing the seller of his intended revocation was inconsistent with the good faith obligation. In these circumstances, however, nuinerous explicit provisions of the Code could have been apphed. Delay in the initial notification of breach can be used as grounds to bar the purchaser from any remedy, imcluding revocation; 56 delay im notifying the seller of a revocation can preclude the right to revoke;57 and the refusal to permit repair, even though goods have been accepted rather than rejected, may be grounds for denying a subsequent revocation of the acceptanee. ${ }^{58}$ The court's use of section 1-203 did not grant the seller any rights that lie did not already possess under other provisions. Use of good faith as a shorthand imdication of a party's rights under more specific provisions does not indicate that the obligation possesses "its own distinctive potential . . . as an independent theory of liability." 59 Given these provisions the court could have and should have reached the same decision whether delay in notification was predicated on forgetfulness, an ignorant hope that the defect would go away, a desire to avoid an embarrassing scene with the seller, or mendacity. Indeed, use of an open-ended good faith obligation instead of the more specific applicable Code provision indicates lack of precision in the court's reasoning and detracts from the judicial development and comprehension of the Code. The case suggests that even when violation of the good faith obligation is announced, the violation may carry no $\mathrm{m}$ dependent legal consequences. ${ }^{60}$

It night be argued that these cases do not deinonstrate conclusively the absence of reinedies for violation of the good faith obligation, but only that multiple recovery will not be permitted when an actor violates more than one legal rule in performing a single activity. If the inanufacturer of a defective product is sued in negligence, breach of

56. U.C.C. § 2-607(3)(a).

57. U.C.C. $\S 2-608(2)$.

58. Section 2-508 refers only to the seller's ability to cure after rejection. Nevertheless, an argument may be made that under section 2-608(3) an aggrieved buyer has the duty to permit cure even after he revokes, at least if revocation is not predicated on previous failures to cure that suggest additional efforts would be futile. See U.C.C. § 2-608(1)(a).

59. Summers, supra note 2, at 199.

60. For cases in which section 1-203 receives similar treatment, see Clark v. International Harvester Co., 99 Idaho 326, 581 P.2d 784 (1978) (section 1-203 used to augment section 2-719). 
rowed additional funds from a dental supply company and granted a security interest to the company in the same collateral previously assigned to the bank. The debtor, however, informed the company that the collateral previously had been assigned to the bank. The court rejected the argument of the second secured creditor's assignee that it was entitled to priority because of the bank's failure to file in all required locations. The court noted that had the second secured creditor seen the properly filed financing statement at the county clerk's office, it would have had sufficient knowledge to disable it under section 9401(2) froin claiming priority because of the unfiled financing stateinent. The court reasoned that oral notification to the second secured creditor placed that creditor in the same position as if it had seen the financing statement in the county clerk's office. ${ }^{51}$ Thus, the creditor's knowledge disabled it from claiming priority over the preexisting interest. The court then noted that by including the phrase "or duty" im section 1-203, the drafters of the UCC intended to impose an obligation of good faith towards third parties as well as parties to a contract, and concluded: "Under the circumstances of this case, it was not good faith to impose a security interest on assets which the debtor had already said were secured to [the petitioner bank]."52

The good faith discussion is superfluous in these circumstances. The conclusion of the court, apparently supported by New York law, ${ }^{53}$ was based on the element of notice. The subsequent imvocation of good faith adds nothing: no additional damages are assessed, no further priority is lost, and no additional property is gained by the estate..$^{54}$ The identical result could be attained solely by citation to section 9-401(2). Inclusion of the good faith discussion merely embellishes the true reason for the holding.

In some cases, courts do write as though violation of the good faith obligation is the primary basis of liability. Closer inspection of the facts of the cases, lowever, indicates that use of the good faith provision does not reflect an independent obligation. Rather, in these cases good faith language is used as a surrogate for other causes of action not explicitly mentioned in the court's opimion.

In a recent case,,$^{55}$ for instance, a purchaser of a fishing vessel de-

51. Id. at 443.

52. Id. at 444.

53. See id.

54. Similar use of the good faith obligation is found in Standard Alliance Indus., Inc. v. Black Clawson Co., 587 F.2d 813 (6th Cir. 1978), cert. denied, 441 U.S. 923 (1979); T \& W Ice Cream, Inc. v. Carriage Barn, Inc., 107 N.J. Super. 328, 258 A.2d 162 (1969). (1977).

55. Peter Pan Seafoods, Inc. v. Olympic Foundry Co., 17 Wasl. App. 761, 565 P.2d 819 
warranty, and strict liability, the successful plaintiff recovers only once, not three times. Similarly, the victim of a contractual breach is entitled to recovery on the breach and nothing more. There are several responses to this argument. First, the courts never explain the absence of a good faith award in this manner. Of course, little should be inferred from silence, but it is unnerving to find no case in which the court says, for example, "Having disposed of the case on the issue of $\mathrm{X}$, we need not address the further claim that defendant violated his obligation to perform his contract in good faith." Second, if an independent remedy is available only when no alternative basis of liability exists, then good faith is dispositive in a very small percentage of cases and perhaps the definition should be restricted to fit only those cases. Third, if the good faith obligation were properly the subject of an independent cause of action, remedy for its breach would not necessarily be the saine as the remedy for the other cause of action in the case, and thus one would expect discussion of each theory of recovery and the appropriate remedy.

Finally, if the good faith obligation has independent vitality that can be addressed by independent remedies, cases should exist in which the obligation is so used. The case that comes closest to addressing good faith as an independent obligation is W.L. May Co. v. Philco-Ford Corp.${ }^{61}$ in which the court denied recovery on plaintiff's claim that a franchisor had failed on termination of the franchise to repurchase inventory. The court intimated the possibility of a different result had violation of the good faith obligation been pleaded and proved: "[P]roof that the manner in which the repurchase election was exercised at the time of termination ainounted to a breach of Philco's implied obhigation of good faith and fair dealing would have been an independent basis for a recovery of damages."62 The court did not explaim, however, how that theory, or the proof necessary to the theory, differed from the theory based on contractual obligation that the court had before it.

\section{The Obligation and Its Remedy: Commercial Good FaITH AND COMmercial GoOd SaMaritanism}

The suggestion that courts have done little to remedy violations of an expansive concept of good faith may imply that courts both can and should do more. As discussed below, there are several reasons why the courts' parsimonious application of the good faith obligation is proper

61. 273 Or. 701,543 P.2d 283 (1975).

62. Id. at 710,543 P.2d at 288 . 
and why arguments for an expansive good faith obligation should be rejected. ${ }^{63}$ Where good faith prohibits limited notions of dishonesty, the costs of interpretation, administration, and renedy are recognized as worth the resulting benefits. This section suggests that those costs increase in number and intensity the further one proceeds froin a narrow interpretation of honesty in fact. They inay multiply to an unacceptable level if good faith is used to police the substantive fairness of a transaction or to convert commercial actors into brothers' keepers.

No attempt is made in this section to define the point at which a definition of good faith becomes "too" expansive. It is argued, lowever, that the requirement soine commentators advocate that one party to a contract inust aid another who has fallen into difficulty through no fault of the first party - a situation that will be referred to as "commercial good samaritamisin"-falls outside the proper boundaries of the good faitli obligation. Expansive notions of good faith share a concept of commercial behavior that embodies altruism or benevolence as well as financial rewards. Altruisin inay be attamable and may actually reflect common commercial conduct. Professor Macaulay's study ${ }^{64}$ evidences the development of an interdependence among commercial actors that minimizes disputes and facilitates resolution of those disputes that do occur. Nevertheless, to the extent that commercial actors choose not to act selflessly, the good faith provisions of the Code should not be used to impose an affirmative duty to aid.

To clarify the issue, this article proposes three situations which, intuitively at least, cry out for judicially compelled altruism. If, on refiection, we would reject application of the good faith provision to provide an independent reinedy in these circumstances, we may inore readily restrict the meaning of good faith in less compelling situations. The following analysis, therefore, is inade im light of these paradigm situations:

Paradigm 1. A buyer of goods openly seizes on a trivial defect, e.g. , a tender one day late where the delinquency does not affect inaterially the buyer's ability to use the goods, in order to reject under a perfect tender rule because the inarket price of the goods lias declined from the contract price. ${ }^{65}$

63. This section does not presume, however, that courts have consciously avoided an expansive interpretation of good faith for the reasons stated herein.

64. Macaulay, Non-Contractual Relations in Business: A Preliminary Study, 28 AM. Soc. REv. 55 (1963); see Leff, Injury, Ignorance and Spite-The Dynamics of Coercive Collection, 80 YALE L.J. 1, 24-26 (1970).

65. Summers considered this conduct a concrete example of bad faith. See Summers, supra note 2, at 205-06. See also Baker v. Ratzlaff, 1 Kan. App. 2d 285, 564 P.2d 153 (1977). Professor Honnold similarly suggested that the good faith obligation might be used to prevent the buyer 
Paradigm 2. A secured creditor who has taken possession of collateral to perfect his security interest discovers information, equally available to the pledgor-debtor but undiscovered by him, that threatens the value of the collateral. The creditor takes no steps to bring the information to the attention of the debtor. Similar situations have arisen unost frequently when an issuer of convertible debentures in bearer form that have been pledged gives notice of redemption that reaches the secured party and not the debtor, and the debentures then lose their convertible feature. Assuming that the creditor was under no duty to discover the notice of redemption and act on it to satisfy his obligation to take reasonable care of the collateral, ${ }^{66}$ and that he nevertheless obtains notice of the impending redemption, e.g., through a newspaper advertisement equally available to the debtor, one could argue that the creditor has an obligation under the good faith provision to notify the debtor and receive instructions. ${ }^{67}$

Paradigm 3. Shortly before his performance under a binding contract is due, a seller of goods informs the buyer of his unwillingness to

from avoiding the contract in these circumstances. See Honnold, Buyer's Right of Rejection, $97 \mathrm{U}$. PA. L. Rev. 457, 475 (1949).

66. U.C.C. $\$ 9-207(1)$. Compare Traverse v. Liberty Bank \& Trust Co., 5 U.C.C. Rep. Serv. 535 (Mass. Super. Ct. 1967) with Siedınan v. Merchant's Bank of New York, 7 U.C.C. Rep. Serv. 881 (Civ. Ct. N.Y. 1970) and Brodhein v. Chase Manhattan Bank, 75 Misc. 2d 285, 347 N.Y.S.2d 394 (1973).

67. It might appear inconsistent to state that one can act "reasonably" for purposes of section 9-207 without also acting in good faith under section 1-203. Reasonable conduct, however, may include conduct that fails to avert a known danger to others. RESTATEMENT (SECOND) OF TORTS $\$ 314$ (1965) provides: "The fact that the actor realizes or should realize that action on his part is necessary for another's aid or protection does not of itself impose upon him a duty to take snch action." Illustrations of the rule make clear that one can disregard with impunity relatively costfree opportunities to rescue others under a rule of reasonableness:

Illustration:

1. A sees $B$, a blind man, about to step into the street im front of an approaching automobile. A could prevent B from so doing by a word or touch without delaying his own progress. A does not do so, and B is run over and hurt. A is under no duty to prevent $B$ from stepping into the street, and is not liable to $B$.

....

4. A, a strong swimmer, sees B, against whom he entertains an unreasonable hatred, floundering in deep water and obviously unable to swim. Knowing B's identity, he turns away. $A$ is not liable to $B$.

Id. Illustrations 1, 4. If, notwithstanding the reasonableness of the creditor's conduct under these traditional rules of nonfeasance, the good-faith obligation is interpreted expansively to require decency and mutual assistance, the creditor in this paradigm can violate section 1-203 without contravening section 9-207.

Nor is such a result illogical. A rule that makes persons liable for failure to avert known dangers creates a disincentive to obtain knowledge that would be helpful for reasons other than rescue of endangered parties. For instance, in the second paradigm a rule that knowledge triggers a duty to rescue could induce lenders to keep certain officers or employees ignorant of financial information which, if they liad, they would voluntarily use to benefit borrowers. See Kronman, Mistake, Disclosure, Information, and the Law of Contracts, 7 J. LEGAL STud. 1 (1978). 
perform unless the contract price is revised in his favor to reflect postcontract market conditions. The buyer pleads inability either to meet the deinand for a price increase or to obtain fungible goods elsewhere on such short notice. Hence he is unwilling to declare an anticipatory repudiation. Instead, the buyer rehes on exhortation and pleas, but apparently to no avail. Notwithstanding the ostensible failure of the buyer's pleas, the seller does perform for fear of the consequences of a breach of contract action; his threats of nonperformance turn out to be only a bluff to try to improve his previous bad bargain. The buyer, relieved but exhausted from the thought of the consequences had the seller not performed, accepts the seller's performance. ${ }^{68}$

There is a parallel in the issue presented by these cases to the tort law question of whether one party can be held liable for refusal to take relatively costless action to rescue another. The rescue duty in tort arises in two ways: first, when the danger is created by the actor upon whoin the duty is imposed; and second, when a special relationship ${ }^{69}$ exists between the person endangered and the potential rescuer. ${ }^{70}$ In the commercial setting, judicial animosity toward imposing affirmative duties to act has been set aside in situations analogous to the first circumstance described above. Thus, in the "lull" cases-in which the obligor's bad faith conduct consists of affirmatively inducing the obligee into a vulnerable position and attempting to exploit the vulnerability-the good faith obligation has been given substantive content. ${ }^{71}$ It seems clear, lowever, that an expansive notion of good faith transcends these few cases and imposes affirmative duties on obligors to "rescue" obligees whose expectations in a transaction have been adversely affected by circumstances not created by the obligor. If there is an analogy to tort liability, it is to those cases in whicli courts have found that a special relationship exists between the rescuer and the rescuee that trig-

68. In this last paradigm, the injury suffered by the buyer is nore ephemeral because the seller has performed. Furthermore, any injury to the buyer results from the seller's affirmative conduct in threatening not to perform. Thus the paradigm does not represent a true good-samaritan situation, where the potential actor is not responsible for the victim's predicament. Nevertheless, this paradigm demonstrates some of the impediments to an expansive interpretation of good faith.

69. See note 22 supra.

70. See, eg., RestATEMENT (SeCOND) OF ToRTs $\S \S 322-323$ (1965), which require an actor who has placed another in danger to avoid materialization of the danger even if the actor, in creating the risk, was not negligent or otherwise acting in a tortious manner. For some consequences of such provisions, see Gillette, Book Review, 60 B.U.L. REv. 383, 392-96 (1980). See note 68 supra.

71. See text accompanying notes $48-49$ supra. 
gers a duty to rescue. ${ }^{72}$ To uphold the analogy in the commercial area, one must argue that the contract itself creates the special relationship. Thus, we might construe good faith to oblige an actor not to realize for himself potential advantages of the circumstances to the detriment of the other. The commercial relationship thus triggers not inerely duties of performance, but also duties of mutual support and aid. It is in this sense that section 1-203 was originally explained to accomplish "due regard for commercial decencies."73

In deciding whether a commercial relationship triggers duties of mutual aid, we first examine the Code's provisions for good samaritanism aside from section 1-203. If other language in the Code embraces opportunities for imposing obligations of mutual aid, it would be consistent to read section 1-203 similarly. The Code, however, is ambivalent toward requiring aid in specific situations, and this ambivalence behes an intention to create a general duty of mutual assistance. The Code embodies the common law requirement that an aggrieved party mitigate damages caused by a breacher, both by explicit limitation of damages to those that could not have been prevented ${ }^{74}$ and, implicitly, by calculatimg damages in a manner that encourages the aggrieved party to secure alternative performance shortly after the breach. ${ }^{75}$ The mitigation requirement may represent a policy of commercial good samaritanism in that it encourages nonbreachers to act with regard for the interests of the defaulting party. Other Code provisions, however, reject the notion of good samaritanism. One of the most blatant rejections is found in section 1-203 itself. Its failure to extend the good faith obligation to the negotiation process ${ }^{76}$ apparently reflects a deliberate choice to permit parties to refram froin disclosing material information to others. ${ }^{77}$ Similarly, one might expect a good samaritan duty to trigger obligations not only toward other parties to a contract, but also to third parties related to other contracting parties. ${ }^{78}$ In hight of this possibility, it seems anomalous with good samaritanism that the priority system of Article 9 comprises a pure race statute. It may be immaterial

72. See C. Gregory, H. Kalven \& R. Epstein, Cases and Materials on Torts 338-60 (3d ed. 1977).

73. See text accompanying notes 20-26 supra.

74. See U.C.C. $\$ 2-715(2)$.

75. See id. \& 2-713, Comment 1.

76. Some commentators argue that the good faith obligation should extend to the negotiation process. See, e.g., Holmes, supra note 2; Summers, supra note 2, at 218.

77. See Report of the New York Law Revision Commission, supra note 36, at 315 (comments of Professor Patterson).

78. Tort law recognizes that one's affirmative obligations to A may be created by one's special relationship with B. See Tarasoff v. Regents of the Univ. of Cal., 17 Cal. 3d 425, 551 P.2d 334, 131 Cal. Rptr. 14 (1976). 
that the first party to perfect his security interest in assets of a debtor had prior notice of a competimg party's unperfected security interest. A good samaritan duty would suggest forbearance froin taking advantage of a prior party's failure to perfect. ${ }^{79}$

The Code's general ambivalence toward commercial good samaritanism fails to clarify the intended scope of section 1-203. We therefore must focus on the normative issue of whether section 1-203 should be used to achieve commercial good samaritamsm. That inquiry would be facilitated if authorization exists to remedy bad faith conduct and if courts can devise a meaningful remedy.

Some Code language supports a remedy for violation of the good faith obligation, however good faith is defined. Section 1-102 directs courts to construe the Code "to proinote its underlying purposes and policies." Though these purposes and policies are generally stated,, 80 they arguably include the specific obligation of good faith conduct, which can be promoted inost effectively by allowing redress for its breach. Section 1-106(2) provides that any obligation declared by the Code "is enforceable by action unless the provision dcclaring it specifies a different and limited effect." 81 Since section 1-203 imposes an "obligation" and does not specify a "different or limited effect" for failure to comply, the Code appears to authorize an independent cause of action to redress bad faith conduct. The term "obligation" in section 1203 itself suggests that the obligee has an enforceable right to the performance of the obligation. It is the ability to enforce that separates the entreaty that one is "obligated" to perform an act from the entreaty that one "ought" to do the act or that it would be expedient for one to do the act. ${ }^{82}$ Unlike the other inotives for acting, failure to fulfill an "obligation" to act implies a violation of the right of the obligee for which he may obtani a remcdy.

79. As noted in the discussion of In re Davidoff, see text accompanying notes 50-54 supra, in some situations a prior financing statement that has not been filed in all required locations is effective against persons with knowledge of the contents of the financing statement. See U.C.C. \& 9-401(2).

80. Section 1-102(2) provides:

(2) Underlying purposes and pohicies of this Act are

(a) to simplify, clarify and modernize the law governing commercial transactions;

(b) to permit the continued expansion of commercial practices through custom, usage and agreement of the parties;

(c) to make uniform the law among the various jurisdictions.

U.C.C. $\S 1-102(2)$.

81. U.C.C. § 1-106(2).

82. See J. RAwls, A Theory of Justice 112-14 (1971); Hart, Are There Any Natural Rights?, 64 Philosophical Rev. 175 (1955). But see R. Nozick, ANARChy, STAte aNd Utopia 91-92 (1974) (questioning Hart's analysis). 
Notwithstanding section 1-106(2), both the ability of courts to fashion remedies for violation of the good faith obligation and the desirability of the attempt are questionable. Three facts support this assertion: no express authorization exists in the Code for imposing such a remedy, despite the favorable language of Article 1; the ambiguity of the good faith obligation causes any remedy for its violation to be administered arbitrarily and unevenly; and, any remedy for bad faith conduct conflicts with and jeopardizes other goals of contract and commercial law without producing countervailing benefits.

\section{A. Authorization to Impose a Remedy.}

Any doubts concerning authorization appear to be foreclosed by sections 1-102 and 1-106.83 Nevertheless, in numnerous cases it is difficult to formulate specific remedies froin these general enabling provisions. The variety of injuries suffered as a result of bad faitl conduct unrelated to a breach of contract does not fit easily within the Code's remedial provisions. This section will demonstrate the existence of that gap and argue that efforts to bridge it would undercut the accepted and justifiable understanding of commercial responsibilities.

The remedy issue poses little difficulty in cases in which good faith is an explicit prerequisite to attaining a certain legal relationship. For instance, section 2-305 permits parties to conclude a contract for sale notwithstanding an open price term. Subsection (2) of section 2-305 allows one of the parties to fix the price term after the conclusion of the contract, but imposes the express requirement of "good faith." 84 The remedy for failure to fix the price in good faith is clear: the price term is void and a new price nnay be supplied by the court. ${ }^{85}$ In effect, good faith is a statutory condition precedent to attaining authority to set the price. ${ }^{86}$ The remedy for failure to exercise good faith is to deny the

83. See notes 80-82 supra and accompanying text.

84. Section 2-305 provides in part:

Open Price Term

(1) The parties if they so intend can conclude a contract for sale even though the price is not settled. In such a case the price is a reasonable price at the time for delivery if

(a) nothing is said as to price; or

(b) the price is left to be agreed by the parties and they fail to agree; or

(c) the priee is to be fixed in terms of some agreed market or other standard as set or recorded by a third person or agency and it is not so set or recorded. good faith.

(2) A price to be fixed by the seller or by the buyer means a price for him to fix in U.C.C. $\$ 2-305$.

85. See, e.g., Harvey v. Fearless Farris Wholesale, Inc., 589 F.2d 451, $461-62$ (9th Cir. 1979) (dicta).

86. Similarly, a contractual condition is a fact or event necessary to produce a change in legal relations. 3A A. Corbin, Contracts $\S 627$, at 11-12 (1960). 
actor that authority.

Arguably, denial of a desired legal status can be used to remedy bad faith conduct even if the good faith obligation is only implied by section 1-203. Thus, although section 2-209, which governs modifications of contract, does not contain any explicit good faith requirement, courts have denied enforcement of modifications extracted in bad faith. ${ }^{87}$ Similarly, if $\mathrm{m}$ our second paradigm ${ }^{88}$ the secured creditor were to discover himself under-collateralized once the conversion feature expired, we could deprive him of the right to demand additional collateral if his inaction was attended by bad faith.

In some cases, however, the condition-precedent analogy does not suffice. Where bad faith consists of nonperformance, i.e., breach or cancellation as im our first paradigm, ${ }^{89}$ it is pointless to characterize good faith as an unsatisfied condition. One might respond that so long as damages for breach of contract are available, there is no reason for additional remedies. This response, however, suggcsts that there is no need for an independent remedy for bad faith conduct im any nonperformance case. As noted earlier, when courts speak of bad faith breaches, they impose remedies based solely on the breach that are not connected to the breacher's good or bad motives.

More important, the condition-precedent remedy is of no help in cases like our third paradigm, ${ }^{90}$ in which alleged bad faith conduct does not affcct the ultimate performance received by the obligee. ${ }^{91}$ In this situation, the victim of bad faith conduct does not want to avoid his legal relationship with the obligor. Thus, denial of the relation does not constitute an effective sanction nor does it vindicate the obligee's interests. In such imstances, an alternative reinedy would give life to the obligation to perform in good faith. In the second paradigm, for instance, the debtor might seek to recover the difference in value of the debentures before and after loss of the conversion privilege. ${ }^{92}$ Alternative remedies, lowever, intensify the doctrimal difficulties of good faith.

87. See U.C.C. \$2-209, Comment 2; Hillman, supra note 2.

88. See text accompanying notes 66-67 supra.

89. See text accompanying note 65 supra.

90. See text accompanying note 68 supra.

91. The third paradigm also is illustrated by deliberate delay in performance that does not harm the promisee's financial position, or a purposeful or malicious faulty performance or nonperformanee in which the promisor is willing to accept the consequences of his breacl.

92. See cases cited in note 66 supra. In these cases the theory of recovery was the creditor's failure to exercise reasonable care with respect to the collateral under section 9-207(1). Our paradigm assumes that the creditor las no such duty to discover the debenture redemption and the issue centers on the creditor's responsibility should it learn of the redemption. See note 67 supra for the argument that failure to disclose information that the creditor had no duty to discover does not constitute unreasonable conduct. 
If the creditor was not acting unreasonably under section 9-207(1),93 no neghigence action can be brought against him for the devaluation of the debentures. No clear statutory authorization exists for any action when he fails to act after receiving actual notice. Authorization may be found by interpreting section $1-106(2)$ as self-executing. But that interpretation merely raises the doctrinal uncertainty to another level. Section 1-106(2) provides no guidance on how to measure damages outside the general principle of section 1-106(1) that the debtor should be placed in the same position he would have occupied had the creditor acted in good faith. No standard determines at what time or place the position of the aggrieved party is to be measured. Assuming fluctuation in the price of the debentures pending redemption, we do not know whether good faith conduct would have led to sale at the highest price, the lowest price, or the last available price. ${ }^{94}$

The difficulty of reading section 1-106(2) to authorize a specific remedy is even more evident with the third paradigm. Here the bargamed-for perfornance has occurred, albeit attended with unanticipated aggravation and dispute. A tort remedy for infliction of emotional distress may be available, but such relief would not be dependent on an obligation of good faith. ${ }^{95}$

One obvious remedy for bad faith conduct would be an award of punitive dainages. The Code, however, expressly rejects such an award "except as specifically provided in this act or by other rule of law."96 Oddly, neither section 1-203 nor any other section that imposes the good faith obligation contams a "specific provision" for punitive damages within the ineaning of section 1-106(1). Courts have thus denied recovery of punitive damages where the act of the wrongdoer does not rise to the level of fraud. 97

93. See note 67 supra.

94. Courts have differed on the appropriate method for assessing damages against a creditor for failure to convert convertible securities in a timely manner. Compare Traverse v. Liberty Bank \& Trust Co., 5 U.C.C. Rep. Serv. 535, 542 (Mass. Super. Ct. 1967) (damages equal the difference between the value of the collateral and its market value if properly converted on the date that the plaintiff had a right to possession) with Reed v. Central Nat'l Bank of Alva, 421 F.2d 113,118 (10th Cir. 1970) (damages equal the difference in value prior to and after the failure to convert, as of the final date for conversion).

95. It is not even clear that the buyer's conduct in this paradigm is sufficiently outrageous to trigger the tort renedy. See W. Prosser, HANDBOoK of THE LAW of TorTs, 49-62 (4th ed. 1971).

96. U.C.C. § 1-106(1). The Code actually uses the phrase "penal damages," but courts uniformly have equated the phrase with punitive damages. See cases cited in note 97 infra.

97. See, e.g., Fousel v. Ted Walker Mobile Homes, Inc., 124 Ariz. App. 126, 602 P.2d 507 (1979); Hall v. Owen County State Bank, 60 Ind. Dec. 221, 370 N.E.2d 918 (1977); Ford Motor Co. v. Mayes, 575 S.W.2d 480 (Ky. Ct. App. 1978); Z.D. Howard Co. v. Cartwright, 537 P.2d 345 (Okla. 1975). 
One may fall back on the "other rule of law" criterion of section 1106(1) and combine that phrase with section 1-103 to find authorization for such damages. Section 1-103 incorporates into the Code those "principles of law and equity" not specifically displaced by particular Code provisions. ${ }^{98}$ Two obstacles, however, prevent incorporation of punitive damages for bad faith. First, the relevant preexisting principles of law and equity deny punitive dainages in the absence of fraud. Modern decisions have awarded punitive damagcs where a party to a contract has engaged in tortious conduct, but the good faith question in such cases is irrelevant or superfluous. ${ }^{99}$ The punitive award flows from the tortious behavior rather than from the absence of good faith. Fraudulent conduct may be reached through separate Code provisions, ${ }^{100}$ without reference to any good faith obligation.

Second, the displacement proviso of section 1-103 proves troublesome. No specific Code provision expressly rejects punitive daunages as a remedy for bad faith conduct, but as a general matter of statutory construction, a principle of law also may be displaced by statutory silence. ${ }^{101}$ Various remedial sections of the Code address impairment of contract and breach of contract, ${ }^{102}$ and the novel remedial principles of these sections demonstrate that the drafters did not hesitate to abrogate common-law contract principles when desirable. ${ }^{103}$ Nowhere, however, does the Code abrogate the common-law reticence to introduce punitive damages into the law of contract. Given the detailed schenie of commercial reinedies that arguably is preemptive, one may conclude that additional judicial gloss on the statutory scheme is displaced.

These arguments that remedies for bad faith conduct do not fit well into the Code's structure may be dismissed as technical nitpicking. If bad faith conduct were otherwise a proper subject for a remedy, it would be odd to deny that remedy because of its mcongruity with statutory language; at most, clarification of the language, rather than dismissal of the reinedy, would be necessary. The absence of an express authorization for a reinedy, however, reflects a subtle rejection of an

98. See U.C.C. § 1-103.

99. See Griffith v. Shamrock Village, 94 So. 2d 854 (Fla. 1957); Oestreicher v. Stores, 290 N.C. 118, 225 S.E.2d 797 (1976); Saberton v. Greenwald, 146 Ohio St. 414, 66 N.E.2d 224 (1946).

100. See, e.g., U.C.C. $\$ \S 1-103,2-721$.

101. Thus, courts adopt the adage expressio unius est exclusio alterius as a tool of statutory construction. See J. Sutherland, 2 Statutes \& Statutory Construction 917, 1055 (1904).

102. See U.C.C. $\$ \$ 2-706$ to $-709,2-712$ to -716 .

103. Most notably, the Code created specific rights to cover a breached contract, to cancel a contract when there has been an anticipatory repudiation, and to obtain specific performance more readily than permitted under common or prior statutory law. 
expansive interpretation of good faith as inconsistent with causal relationships in commercial law.

Damages in commercial situations compensate for economic harm caused by one of the contracting parties. The injury suffered by the aggrieved party, however, is his imability to obtain a stipulated opportunity for gain. ${ }^{104}$ In the traditional breach of contract situation, that inability results from one of two events: either affirmative conduct or omission by the alleged breacher that deprives the injured party of receipt of goods, money, and services to which he was entitled by the terms of the bargain, or materialization of a risk that was allocated to the breacher. ${ }^{105}$ Ouly in the third paradigm above, the case of the bluff of nonperformance, did either of these events occur. There, the bad faith actor affirmatively threatened nonperformance, causing harm to the buyer. In the other cases, however, it is difficult to understand how the alleged bad faith conduct could cause any injury.

In the first paradigin the seller's failure to obtain the expected benefit from his contract is triggered by his own failure to coinply with assumed obligations for reasons beyond the control of the buyer. Indeed, that initial, trivial breach emerges froin inaterialization of a risk which the seller assumed, presuniably because he beheved he was in a superior position to control the occurrence of the risk. In this context, it is difficult to contend that the buyer's failure to minimize the effects of the risk once it materialized is the "cause" of the seller's failure to realize his anticipated opportunity for gain. If "cause" of such failure is defined with sufficient breadth to encompass the omission to aid another contracting party who faces imjury from materialization of a risk he assumed, the responsibilities of contracting parties become awesoine in scope. Commercial responsibility would entail not ouly compliance with one's affirmative obligations, but also forbearance from self-interested action that conflicts with the interests of other parties. Failure to help others realize their opportunities for gain translates into responsibility for their subsequent loss. The commercial actor becoines responsible not simply for keeping his promises, but also for ensuring that the optimal state of commercial affairs exists after the concerns of all parties to the transaction have been considered. If in our third paradigm,

104. D. Dobbs, Remedies 786-87 (1973); H. Hart \& A. Honore, Causation in the Law 278 (1959).

105. See H. HART \& A. HONORE, supra note 104, at 287-91, for an analysis of how risk allocation may replace a strict causal inquiry in determining on which party a loss should fall. The role of risk allocation in restricting excuses from contractual obligations is explored in Berman, Excuse for Nonperformance in the Light of Contract Practices in International Trade, 63 CoLUM. L. REv. $1413,1415-20$ (1963). For a general critique of causal explanations of bad samaritanism, see Mack, Bad Samaritanism and the Causation of Harm, 9 PHILOSOPHY \& PUB. AFF. 230 (1980). 
for instance, the seller's request for modification were made from an honest conviction that he would otherwise suffer, the buyer who refused to grant the request would have "caused" that mjury to the seller. ${ }^{106}$ This notion of negative responsibility similarly means that in our second paradigm the secured creditor's failure to notify caused the devaluation of the debtor's assets. This result would obtain notwithstanding that, by hypothesis, the debtor had equal access to the information and that the secured creditor-had no original duty to notify the debtor of the redeinption. ${ }^{107}$

Whether or not hability obtaims for causation of these consequences requires further analysis. For present purposes, it is important to note that the concept of causation that underlies an expansive notion of commercial good faith is vastly different from traditional concepts of causation and requires extended notions of responsibility.

The difficulty in finding authorization for a remedy in the commercial good samaritan situation, then, is not the existence of gaps in doctrinal language, but that imposition of a remedy in these circumstances alters the concept of responsibility recognized in contract and commercial law. It is difficult to believe that the drafters intended the concept of "commercial decency" to accoinplish such a result without more elaborate explanation.

\section{B. Administrative Difficulties in Remedying Bad Faith.}

The difficulty of identifying commercial good samaritanism in a specific factual setting supports rejection of the extended responsibility inherent in such conduct. Regardless of whether the tern "Ionesty in fact" excludes only acts of trickery and deceit or also broader categories of taking advantage or profiteering from misfortune of others, courts and commentators seein to agree that the test is to be applied subjectively. ${ }^{108}$ Proof that other commercial actors would have perforined differently does not suffice to deinonstrate the absence of good faith.

106. See Missouri Pub. Serv. Co. v. Peabody Coal Co., 583 S.W.2d 721 (Mo. Ct. App.), cert. denied, 444 U.S. 865 (1979), where the court rejected such a use of the good faith obhgation. Even if this causal relationship were admitted, it might be contended that "infliction" of the injury was justified if granting the inodification was unduly expensive to the buyer. The contention in this article, however, is that such an inquiry should not be reached because the buyer has not caused the seller's injury.

107. For a broad-based attack on the notion of negative responsibility for its restrictions on individual hberty, see Williams, $A$ Critique of Utilitarianism, in UTILITARIANISM: For \& AGAINST 93-96, 108-18 (J. Sinart \& B. Williams eds. 1973). For the argument in the context of tort law, see Epstein, A Theory of Strict Liability, 2 J. LEGAL STUD. 151 (1973).

108. See, e.g., Farmers Coop. Elevator, Inc. v. State Bank, 236 N.W.2d 674 (Iowa 1975); Balon v. Cadillac Auto. Co., 113 N.H. 108, 303 A.2d 194 (1973); Dugan, supra note 2, at 11-12; Farnsworth, supra note 2, at 671. 
The obhgor is not expected to comport with conduct that he is incapable of performing. The obligation requires only that he perform to the best of his ability.

The subjective, aspirational nature of the obligation creates two related difficulties in addressing its violation. First, once the content of good faith extends beyond the narrow scope of honesty, a vagueness in definition exists that impedes agreement on the components of good faith conduct and thus interferes with the directive to act in good faith. Second, subjective differences in the ability to comply with a command to act in good faith create difficulty in identifying whether the obligation has been satisfied and thus may promote misapplication of remedial sanctions.

1. The Problem of Vagueness. The command "go and act in good faith" is vague because the actor and the commander may disagree on the components of good faith conduct. Stripped of its limitation to honesty and imbued with its utility as an "excluder," 109 good faith may mean different things to different obligors as well. An obligor who intends to comply with his legal responsibilities may conduct his affairs in a manner consistent with his concept of good faith, only to discover that his values differ materially from those of the obligee or of a third party who sits in judgment of whether the command has been obeyed.

The possibility of disparate concepts of good faith may increase when the obligation extends to failure to prevent harm in addition to creation of circumstances that, in the everyday sense of the term, bring about harm. Where the obligor creates the situation that requires rescue of the obligee, the causal relationship is sufficiently obvious to allow agreement on the components of good faith conduct. Where, however, good faith conduct assertedly consists of preventimg harm due to circumstances not created by the obhigor, the absence of a direct causal relationship increases the likelihood of disagreement over whether the obligor must act and what he must do to fulfill the expanded obhigation.

The possibility of variations in the requirements of good faith even in a single situation pervades cases such as Mott Equity Elevator $v$. Svihovec, ${ }^{110}$ where the court was confronted with the question of whether a purchaser of wheat was entitled to delivery of the goods. The plaintiff-purchaser argued that the contract phrase "March Delivery" mandated delivery in March or at such later time as the plaintiff

109. Summers, supra note 2, at 196.

110. 236 N.W.2d 900 (N.D. 1975). 
requested delivery. The defendant-seller argued that "March" meant during the month of March and that he was thus entitled to sell his wheat at a higher market price when plaimtiff refused to accept the wheat during that month. Plaimtiff pleaded that a shortage of boxcars precluded acceptance of delivery earlier than September, when market prices fortuitously had doubled from the contract price. In its discussion of the parties' obligations, the court noted that even if there had been a boxcar shortage, the plaimtiff could have accepted the wheat and built or rented additional storage space to transfer the risk to itself. ${ }^{111}$ The court refused, however, to impose on the farmer the affirmative obhigation to notify the plaintiff of the impending resale of the wheat. Fimally, the court considered that the fariner had not acted in bad faith when he resold his wheat shortly after plaintiff refused to accept dehvery and also that he was not delaying resale to take advantage of a rising market. ${ }^{112}$

The case demonstrates conflictimg notions of the components of good faith and the nebulous nature of the concept. The court's imposition of an obligation on the buyer to accept the wheat amounts to an interpretation of the Code command "act in good faith" that embodies affirmative duties of incurring costs of additional storage space if railway car shortages make acceptance of scheduled deliveries difficult. Nevertheless, the defendant farner, who might have avoided further altercations had he inforined plaintiff of his intention to deliver or resell the wheat, was not obligated by any notion of good faith to undertake that relatively effortless task smce the law did not explicitly mandate such notice. ${ }^{113}$ The court intimates that had the farner been motivated by the ability to profit from resale of his goods in a rising market, its decision imight have been different. The defendant might have been held to have violated a good faith obligation, i.e., he could not have taken advantage of the fortuitous market shift. ${ }^{114}$ Recitation of the different criteria by which good faith conduct may be measured suggests that the concept may be too vague to expect courts to remedy its violation with evenhandedness or consistency.

Vagueness in the concept of good faith would be of little importance if it were a temporary problem. It imght be argued that definitional vagaries exist only because courts have not yet confronted a sufficient number of cases to clarify the types of conduct prohibited by section 1-203. Over time, the argument continues, courts will face suffi-

111. Id. at $906 \mathrm{n.2}$.

112. Id. at 909.

113. Id

114. $I d$. 
cient similar litigation to create definite rules to govern the seemingly nebulous law. Eventually, the courts will develop a general standard against which specific conduct can be ineasured to ascertain whether that conduct should be prohibited. Applying this general standard will result in the expedient determination of compliance with the good faith obligation. ${ }^{115}$

The flaw in this argument is that the vagueness problem is not suited to temporal solutions. Philosophers and linguists have criticized the belief that specific content can be derived from unoral or normative phrases by analysis of the context in which those phrases are used. ${ }^{116}$ It is possible that "good faith" is not susceptible to the type of perspicuous paraphrase that allows us to comprehend from ordinary usage of the term precisely what the speaker ineans. Indeed, it is probable that different judges will mean different things when using the phrase, thereby undermining any atteinpt to derive a single meaning or single principle from the coinbined usages. Moreover, even if all judges concur in a primciple that elnbodies "good faith," they may fail to make important distinctions in conduct. ${ }^{117}$ Failure to aid a party to the contract may be justified as too costly in a given situation but not recognized as such under a principle of comınercial good samaritanism.

Professor Summers probably would see no need to develop even a general meaning for "good faith" as that phrase is used in section 1-

115. See Ehrlich \& Posner, An Economic Analysis of Legal Rulemaking, 3 J. LEGAL STUD. 257, 266 (1974).

116. Sce R. Brandt, A THEORY OF THE Good and the Right 5-10 (1980); Hare, Rawls' Theory of Justice, in ReADING Rawls 81, 86 (N. Daniels ed. n.d.).

117. We may also have a concern that judges have neither the training nor the temperament to engage in the reflective process that arguably allows for extraction and justification of normative principles froin vague phrases. See Daniels, Wide Reflective Equilibrium and Theory Acceptance in Ethics, $76 \mathrm{~J}$. PHLosophy 256 (1979). Distrust of the judiciary is a common rationale for preferring formal rules over more flexible standards or primciples for legal decisionmaking. See R. WASSERSTROM, The JUdiCial DeCision 75-79 (1961); Kennedy, supra note 8, at 1688. Topical justification for distrust of judicial attempts to clarify vague normative standards is evident in judicial applications of the "traditional governmental activity" standard of a state or local government. This standard defines those local functions that are free from federal regulation under the tenth amendment. See National League of Cities v. Usery, 426 U.S. 833 (1976). The decisions applying the standard display a disarming degree of idiosyncratic jurisprudence. See, e.g., Virginia Surface Mining \& Reclamation Ass'n v. Andrus, 483 F. Supp. 425 (W.D. Va. 1980), aff'd in part, rev'd in part sub nom. Hodel v. Virginia Surface Mining \& Reclamation Ass'n, 101 S. Ct. 2352 (1981); Jordan v. Mills, 473 F. Supp. 13 (E.D. Mich. 1979). Compare Brotherhood of Locomotive Eng'rs v. Staten Island Rapid Transit Operating Auth., 100 L.R.R.M. 3154 (E.D.N.Y. March 5, 1979) (commuter rail service does not constitute traditional governmeutal activity suffcieut to preclude application of the federal Railway Labor Act) with Umited Transp. Umion v. Long Island R.R., 634 F.2d 19 (2d Cir. 1980) (state-run commuter rail service does constitute traditioual governmental activity sufficient to preclude application of the federal Railway Labor Act), cert. granted, 101 S. Ct. 3107 (1981). 
203. He argues that "good faith" is a phrase without general meaning, but serves solely to exclude "a wide range of heterogeneous forms of bad faith." 118 His use of the phrase appears to be situation specific, intended only to rule out precise forms of bad faith conduct in given circumstances. If the good faith provision is, however, to be institutionally useful without creating opportunities for underimclusive and overinclusive applications, it cannot be defined as the absence of bad faith. Opinions probably would differ about the existence of bad faith conduct in a specific situation, and to the extent that disagreenent persists, the saine institutional difficulties in creating and enforcing a remedy affect the determination of bad faith conduct.

In a non-Code setting, it is possible to envision case-by-case enforceinent of a vague good faith obligation. The broad discretion intplied by Summers's analysis currently is exercised by the German courts in application of article 242 of the German Civil Code. This provision is at least as broad as its Uniform Commercial Code counterpart: "Obligations shall be performed in the manner required by good faith, with regard to commercial usage."119 Notwithstanding the vagueness of the German obligation, unqualified even by a limitation to honesty in fact, one distimguished commentator noted that German judges have utilized article 242 as a "roving searchlight" to identify "injustice" in particular cases "within the limits of their own function and when they had or could devise workable ineans to redress it."120

The German experience suggests the possibility that an iniprecise standard of good faith can have independent status and still be enforced with sufficient consistency to avoid the administrative difficulties addressed above. Indeed, Professor Dawson concludes that "the requirements of 'good faith' have transformed the law of contracts and have penetrated deeply throughout the whole of German private law."121 The German experience with article 242, however, inay not be readily transportable to section 1-203 of the Code. As Dawson points out, German judges inay enjoy more acceptance than their American brethren in the role of guardian of the community's morals. ${ }^{122}$ That so few cases have arisen in which the good faith provision appears to inake a substantive difference suggests the American judiciary's uneasiness in assuming a similar function. Moreover, some of the German

118. Summers, supra note 2, at 201.

119. See J. DAwSON, THE ORACLeS of LAw 461-502 (1968); Dawson, Unconscionable Coercion: The German Version, 89 HARv. L. Rev. 1041, 1044 (1976).

120. Dawson, supra note 119, at 1069.

121. Id. 1045.

122. Id. 1124. The reluctance of common law judges to assume such a role is explored in Atiyah, Judges and Policy, 15 IsRael L. REv. 346 (1980). 
cases suggest that article 242 is used in circuinstances that American law addresses under more specific provisions. ${ }^{123}$ For instance, numerous cases concerning rights to payment have arisen as a result of postwar currency alterations. These same cases probably would be decided in this country under the impracticability provisions of the Code ${ }^{124}$ rather than under the more ambiguous notion of good faith. If article 242 permits German judges to do what American judges already are directed to do by statutory and common law, it is of minimal value as a comparative model. Indeed, article 242 may support the conclusion that cases in which a sense of equity or the need to compel altruism demands nonenforcement can be handled by existing doctrines and thus there is less of a need for an expansive interpretation of section 1203.

2. The Possibility of Misapplication. Even if courts can overcome the definitional vagaries and agree on the components of good faith conduct - or the kinds of bad faith conduct that are to be excluded under section 1-203-they must demonstrate that the obligor has not complied with the good faith obligation, a difficulty that has been termed "nonverifiability" in another context. ${ }^{125}$ Failure to identify accurately the presence or absence of bad faith conduct will result in overenforcement of sanctions for violation of section 1-203, thereby punishing conduct that does not contravene standards of proper behavior, or underenforcement, thereby jeopardizing equitable treatment of commercial actors. ${ }^{126}$

Advocates of the gap-filler function of the good faith obligation may cite examples of egregious behavior that all reasonable persons would identify as bad faith conduct but that fall short of constituting a breach subject to a specific Article 2 remedy. An independent remedy under section 1-203 at least permits a court to reach those cases and fill the gap. In such situations, however, the egregious nature of the obligor's conduct suggests the kind of deceit or lying that can be addressed by a narrow interpretation of the obligation. For instance, Professor Patterson explained the reach of the good faith obligation by reference to Price v. Spielman Motor Sales Co. ${ }^{127}$ In that case, the plaintiff had

123. See E. Cohn, Civil Law, in Manual of German Law 59-62 (1st ed. 1950). Dawson reports that the article has been employed with startling frequeucy - sufficient to fill a volume of 1388 pages. See Dawson, supra note 119, at 1045 n.5.

124. See U.C.C. $\$ 2-615$.

125. See Henderson \& Pearson, Implementing Federal Environmental Policies: The Limits of Aspirational Commands, 78 Colum. L. REv. 1429, 1435 (1978).

126. See R. Posner, Economic ANalysis of LAw 424-25 (2d ed. 1977).

127. 261 A.D. 626,26 N.Y.S.2d 836 (1941). 
agreed to purchase a truck from defendant and was allowed a trade-in credit of $\$ 227.50$. The contract prepared by the defendant permitted him to revalue the trade-in truck at the time of delivery of the new truck. When that time arose, five days after the contract was signed, the defendant reappraised the used truck at $\$ 125$ and refused to deliver the new truck without an additional payment of $\$ 102.50$. The court implied from the contract a covenant not to reappraise the value of the used truck without establishing some grounds "other than the lapse of five days of time."128 Though the court used language of good faith in reaching its decision, it clearly beheved that the unexplained change in price indicated intentional deceit of the buyer. Common law equitable principles and remedies are sufficient to address that kind of fraud, trickery, and over-reaching. A narrow interpretation of the good faith obligation encompasses these same avenues of redress; the expansive interpretation is unnecessary. ${ }^{129}$

Presumably, a novel remedy would be helpful in cases where conduct is not egregious and does not rise to the level of obvious deceit or fraud but is nonetheless suspect. A case in point might have occurred in Price had the defendant reappraised the car for $\$ 200$. In that case the court might have been less willing to cry "fraud" or "dishonesty," though it might have remained skeptical about the defendant's regard for the bargain he had previously struck. It is precisely these cases in which bad faith is less obvious, however, that present the problem of nonverifiability. Short of confession by the defendant, it is difficult to determine whether a revaluation to $\$ 200$ was "dishonest" or commercially unreasonable.

A further example of suspicious, albeit nonegregious, behavior nay help to clarify the point. In Lee v. Wood Products Credit Union, ${ }^{130}$ a non-Code case, the plaintiff brought an action for conversion after the defendant credit union repossessed his automobile. A jury awarded plaintiff both general and punitive damages, ${ }^{131}$ but the trial court granted a judgment n.o.v. as to the punitive damages. On appeal, the Supreme Court of Oregon reinstated the punitive damage award. ${ }^{132}$

128. Id. at 629,26 N.Y.S.2d at 839 .

129. See U.C.C. $\$ \S 1-103,2-302,2-721$; Underwood v. Monte Asti Buick Co., 73 Pa. D. \& C. 2d 773, 20 U.C.C. Rep. Serv. 657 (1976). In Umlas v. Acey Oldsmobile, Inc., 62 Misc. 2d 819, 310 N.Y.S.2d 147 (1970), the factual situation was similar to Price, except that on reappraisal the value of the trade-in was determined by the dealer to have decreased from $\$ 400$ to $\$ 50$. There the court implied an obligation to reappraise a used car in good faith from section 2-103.

130. 551 P.2d 446 (Or. 1976).

131. Punitive damages were available since the action was brought in tort for conversion rather than on a contract theory.

132. 551 P.2d at 449. 
The court concluded that although plaintiff had inade several delinquent payments and was in default at the time of the repossession, the credit union's previous waivers of delinquency precluded it from repossessing without advance notice of unwillingness to tolerate further late payment. The court recognized that if the credit union had acted under a mistaken but good faith belief that it was legally entitled to repossess the automobile, no sufficient basis would exist for an award of punitive damages. But the court found that the record contained sufficient facts from which a jury could liave found bad faitl conduct. ${ }^{133}$

The evidence suggested that defendant's branch manager bore ill will toward the plaintiff. The manager had refused partial payments and had insisted on accelerated payinent of the full balance. Employees of the credit union had attempted to block the plaintiff from noving his car from defendant's property after a "heated argument" with the manager, who subsequently reported the car as stolen. The court's opinion suggests that such conduct indicates that the credit union's subsequent repossession was motivated by considerations inconsistent with good faith. ${ }^{134}$ Logically, lowever, no inconsistency may exist. The manager may have had great personal animus against the plaintiff, but his actions may have been motivated entirely by business considerations. Certainly the good faith provisions do not require a party to a commercial transaction to like the person with whom he is dealing. The court apparently was unable or unwilling to determine how the manager would have acted but for the animus, e.g., by coinparing defendant's course of conduct in this case with his conduct in other cases of delinquent debtors. Thus, in close cases-where a novel remedy for bad faith is theoretically most beneficial-the nonverifiable nature of the defendant's bona fides may interfere with accurate or justified application of sanctions.

\section{Protecting the Bargain of the Parties.}

The discussion thus far has centered on the difficulties that an expansive good faith obligation would create for judicial implementation: how to find an appropriate remedy and how to identify the offensive conduct. An expansive obligation, however, would produce analogous difficulties for the parties to the transaction. Although the Code covers virtually all areas of commercial transactions, with few exceptions parties may agree to alter its provisions. ${ }^{135}$ The parties, therefore, inay

133. Id

134. $I d$

135. See U.C.C. \& 1-102(3). 
structure their relationship in their own best interests to attain the certainty and predictability requisite to commercial law in a market econoiny. ${ }^{136}$ Absent fraud or overreaching prohibited by provisions other than section 1-203, the parties by themselves should negotiate an agreement that approximates an equilibriuin between risks assumed and prices paid. When the parties fail to provide specifically for allocation of a risk or responsibility, however, the Code supplies the allocation. Parties inay choose to rely on the Code allocations, thus reducing the amount of necessary bargaining; or, they may concentrate on certain aspects of their bargam, aware of the consequences of a failure to do so. The parties, however, can only determine with accuracy whether to accept or alter the Code's allocations if the legal consequences of those allocations are certain and predictable. As argued below, an expansive good faith obligation undermines the predictive capacities of commercial actors without producing countervailing benefits.

An expansive interpretation of the good faith obligation invites the judiciary to "do justice" in particular cases. ${ }^{137}$ For example, Summers's advocacy of good faith as a means for excluding certain conduct from acceptable commercial behavior appears to be predicated on the ability of and desirability for judges to make ad loc determinations of whether permitting specific commercial conduct would be "just." 138 The danger is that such ad lioc judgments can undermine specific rules of law on which commercial actors depend in making contractual arrangeinents. The result inay be an individualized jurisprudence in which judicial discretion exists to alter risks previously allocated between the parties. This is not to argue that the Code should utterly "control the courts and compel decision." 139 An absolute, relentless degree of certainty might require courts to enforce unfair bargains and opprobrious conduct. Nor must one share Professor Atiyah's concern that the extension of judicial discretion to define legal rights comes at the expense of "the individual's freedoin to plan and order his own life and [portends] a corresponding growth in the power and paternalisin of

136. See P. ATTYAH, supra note 5, at 402 . In light of a party's ability to negotiate terms, some judges have exercised healthy cynicism for attempts to avoid contractual terms after materialization of assumed risks. "The contractors had a ready escape from their difficulty by insisting upon a contract before they used the figures; and in commercial transactions it does not in the end promote justice to seek strained interpretations in aid of those who do not protect themselves." Jaunes Baird Co. v. Gimbel Bros., 64 F.2d 344, 346 (2d Cir. 1933) (Hand, J.).

137. Witness the German courts' facility to "identify injustice" under article 242 . See text accompanying notes 119-24 supra.

138. See Summers, supra note 2.

139. See note 29 supra and accompanying text. 
the state."140 If the parties, however, cannot predict whether their bargained-for allocation will survive the "roving searchlight" of good faith, negotiation inay be skewed from the model the Code seeks to create. The same vagueness in definition that may lead a judge to misapply a remedy for a violation of the good faith standard may also induce a risk-averse commercial actor, fearful of being penalized for violation, to avoid behavior that is not in fact bad faith. He may "invest in the avoidance of risky [and potentially bad faith] activities resources greater than the expected cost of these activities." 141

Superficially, it appears that good faith, however defined, is consistent with the objectives of a certain, predictable corpus of commercial law. To the extent that good faith fosters promise-keeping, commercial actors can rely inore readily on each other's forthcoming performance. In the absence of that increased assurance, commercial actors who fear delay in coinpensation or ultimate undercompensation in the event of breach may attempt to insure against such losses by raising costs to others of entering into a contract. ${ }^{142}$ The additional cost nay take the form of higher prices (intended to include an "insurance premium" to cover losses suffered due to breaches of other contracts) or clauses intended to deter breaches. ${ }^{143}$ Existence of an enforceable good faith principle that discourages breach presumably reduces the uncertainty of performance and the costs associated with that uncertainty.

An expansive definition of good faith, however, nay also serve as a source of uncertainty if it permits judicial modification of legal rules rehed on in the parties' contractual arrangements. The costs of entering into a transaction are reduced to the extent that the parties are certain of the consequences of contract terms and can predict who will bear specific risks. Existence of a broad primciple, judicially applied and not capable of disclanner by bargaining, introduces an element of uncertainty that is likely to increase risks and raise costs at the contract fonnation stage.

Our first paradigm-concerning the buyer who rejects a late tender because of a inarket decline that renders the contract disadvan-

140. Atiyah, From Principles to Pragmatism: Changes in the Function of the Judicial Process and the Law, 65 IowA L. REv. 1249, 1272 (1980). Atiyah's attempt to reconcile the "authoritarianism" of principle with the uncertainty of ad hoc "pragmatic" decisions is of central interest.

141. Ehrich \& Posner, supra note 115, at 262.

142. This is the position taken in Burton, supra note 41, at 392-93.

143. See Goetz \& Scott, Liquidated Damages, Penalties and the Just Compensation Principle: Some Notes on an Enforcement Model and a Theory of Efficient Breach, 77 CoLuM. L. REv. 554 (1977). 
tageous to him ${ }^{144}$-illustrates this point. Initially one might assume that interpretation of the good faith obligation to prevent rejection in such a case advances the certainty of contractual relations because sellers' expectations will not be defeated by technical nonconformities in their tender of performance. Code provisions other than the good faith requireinent, however, already establish rules that provide parties to the contract with certainty of legal rights. If, in our example, the goods had been tendered subsequent to the due date (and the delay had not been induced by any conduct of the buyer), the buyer who wished to take advantage of the depressed market might breathe an initial sigh of relief over his good fortune. He might assume that he is entitled to reject the goods on arrival and cancel the contract since the Code enbodies common law requirements of perfect tender. ${ }^{145}$ If the seller feared his inability to deliver by a specific date, he could have bargained for a later date or for a clause giving him latitude in the delivery tinie. Either solution would have unaintained the certainty of the parties' positions. An expansive reading of good faith, however, inay preclude the buyer from taking advantage of the market downturn-and avoiding his bad bargain-unless he can deinonstrate that acceptance of the nonconforming tender would cause him some injury other than the loss of his opportunity to avoid his bad bargain. It is difficult to fit the buyer's rejection of tender into traditional notions of dishonesty. He has not hed or in any way created the risk that causes the delayed delivery, and he may even admit that but for the market drop he would have waived the nonconformity. Nevertheless, the availability of an expansive interpretation of good faith reduces his ability to rely on the seller's breach to cancel the contract.

From the standpoint of the commercial actor and his legal advisor, therefore, the most iniportant consequence of expanding good faith enforcement to this paradigm relates to their ability to predict the actor's lcgal rights and thus the legal consequences of his conduct. It is unclear whether the attorney can advise his client that cancellation of the contract with the defaulting seller is appropriate under an expansive

144. See Baker v. Ratzlaff, 1 Kan. App. 2d 285, 564 P.2d 153 (1977). See text accompanying note 65 supra.

145. U.C.C. \& 2-601. It is unclear whether the seller would have the opportunity to cure the late tender under section 2-508. Subsection 1 of the cure provision cannot be used because it applies only when the time for performance has not expired. The negative implication of that provision is that subsection 2 of section 2-508 inust apply to permit cure in cases where the time for performance has expired. Nevertheless, subsection 2 requires that the seller has a further reasonable time to substitute a "conforming" tender. It is difficult to envision how a subsequent tender conld ever be "conforming" when it is in substitution for a tender that was rejected on account of its lateness. See U.C.C. § 2-106(2). 
good faith standard. He must determine whether the client will be affected adversely - beyond the loss of a better bargam - by the nonconformity. Regardless of the difficulty of such a determination, the need to make the inquiry at all introduces into sales law the notion of material breach that is rejected explicitly by the host of provisions concerning perfect tender and cure. ${ }^{146}$

Perhaps this argument's reliance on certainty of legal consequences proves too much. If we value certainty as a means to ensure planning and finality in the transaction, rigid adherence to inflexible legal rules may be counterproductive. If market price, for instance, should decrease between the time of contract and the time for performance, the buyer, certain of his ability to avoid the contract on an imperfect tender, may go out of his way (overinvest his resources) in an attempt to discover a trivial breach. ${ }^{147}$ In anticipation of such buyer behavior, a seller might overinvest in the inspection of goods to ensure compliance with perfect tender requirements. In either event, absolute certainty of the legal rights of the parties promotes wasteful conduct. An expansive good faith obligation would disable the buyer from rejecting in such circumstances and thus would remove the reason for overinvestment. ${ }^{148}$

If there were no other safety valve available to prevent the waste inherent in the possibility of rejections for trivial defects, use of the good faith obligation might therefore appear justifiable. The need to invoke an expansive obligation in such circumstances, however, seems doubtful. If there is a real concern over the quality of the merchandise, the parties have incentives to bargain over price reductions or other mutually acceptable remedies without resort to legal doctrines. ${ }^{149}$

146. See R. BRAUChER \& R. Riegert, INTRODUCTION to Commercial Transactions 30507 (1977); J. WHITE \& R. SUMmers, HANDBOOK OF THE LAW UNDER THE UNIFORM COMMERCLAL CODE 303-05 (2d ed. 1980). Cf. Miniter, Buyer's Right of Rejection: A Quarter Century Under the Uniform Commercial Code, and Recent International Developments, 13 GA. L. Rev. 805 (1979) (examining the concept of substantial impairment as a test for determining breach).

147. See K. Lleweliyn, Cases and Materials on Sales 302 (1930); Eno, Price Movement and Unstated Objections to the Defective Performance of Sales Contracts, 44 YALE L.J. 782 (1935).

148. See Summers, supra note 2, at 205-06.

149. See Schwartz, Cure and Revocation for Quality Defects: The Utility of Bargains, 16 B.C. INDUS. \& COM. L. Rev. 543, 547-51 (1975). In this article, Schwartz argues that the cure provision of the Code permits sellers to force unwanted "repaired" goods on buyers who have bargained for "new" goods which have greater value. He argues that cure therefore shifts the cost of nonconformity from sellers to buyers and may create the very economic waste that cure is supposed to avoid. Schwartz's argument assumes that buyers of goods that require repair will beheve that the goods they receive after cure are something other than new goods. Schwartz's view of consumer expectations is not necessarily correct. Intuitively, it seems that buyers of goods anticipate that new goods often require adjnstment, and therefore the adjustment process is inhereut in the newness of the goods. Indeed, the existence of warranties that promise repair indicates to consumers 
Where disagreement remains, however, the Code provides a specific remedy of cure that should accomplish the same objective of reducmg wasteful conduct while preserving certainty of legal position, without creating expansive and vague obligations for the parties. The cure remedy permits a seller whose goods have been rejected to remedy the nonconformity and re-tender the goods within the time agreed on for performance. ${ }^{150}$ A buyer seeking to avoid his bad bargam would be unlikely to invest time or resources im discovering a nonmaterial defect if the known consequence of his rejection is to give the seller an additional opportunity to tender conforming goods. ${ }^{151}$

There are, however, situations in which a reduction in certainty may be necessary to achieve some other objective of commercial law. Obvious cases imclude nonenforcement of contract terms imposed through fraud or bad faith im its narrow sense-lying or cheating. In such cases, one assnmes that setting aside the contract terms will result in a net gain for commercial practice-a position that will be referred to as a superior or optimal state of affairs. It is necessary to inquire, therefore, whether the commercial good samaritan obligation can be justified as a means to promote achievement of a superior or optimal state of affairs. ${ }^{152}$

the possibility of a need for adjustment of the goods after purchase. Thus, materialization of the possible need for adjustment does not alter the "new" status of the goods and does not impose any unexpected costs on the buyers. If an idiosyncratic buyer really would feel a loss if the goods he purchased required adjustment in order to perform properly, he could bargain for a "no repairs" clause in the contract or for a waiver of the seller's right to cure.

There may be situatious, of course, in which the adjustment is so drastic that even the nomidiosyncratric buyer would incur costs in accepting the adjusted good. In such cases, however, the mere existence of such costs to the reasonable buyer suggests that the "cured" tender is not a "conforming" tender as required by UCC section 2-508(1). See U.C.C. § 2-106(2). This interpretation permits reconciliation of Wilson v. Scampoh, 228 A.2d 848 (D.C. Ct. App. 1967) and Zabriskie Chevrolet, Inc. v. Smith, 99 N.J. Super. 441, 240 A.2d 195 (1968). In Wilson the court indicated that minor adjustments, which all reasonable buyers might assume are required on new complicated goods (here, a color television), did not impose costs on the plaintiff. The court apparently would not have, however, accepted major adjustments and might not have considered an attempt to tender a television that had suffered such an adjustment to be conforming. $228 \mathrm{~A} .2 \mathrm{~A}$ at 850. That reading is supported by Zabriskie, in which the court held that the buyer of a new car with a defective transmission did not have to permit cure of the defect. Presumably, that adjustment was so significant that the good could no longer be considered a "new" car.

150. U.C.C. § 2-508.

151. The ability of the Code to balance the perfect tender rule's certainty against the possibility of its abuse through rules of cure and revocation of acceptance is explored in J. WHITE \& $R$. SUMmers, supra note 146, at 304-05.

152. This causation analysis, see notes 104-07 supra and accompanying text, is concerned only with the relationship between the obligor's good faith conduct and the creation of the obligee's phight. If the obligor does not put the obligee in a position where assistance is necessary, the causation analysis indicates that it is not bad faith for the obligor to refuse to give assistance. The "state of affairs" analysis is concerned only with the consequences of the obligor's conduct. If the 
One might contend that no reason exists to protect the certainty that permits buyers to take advantage of fortuitous technical breaches. The buyer in the first paradigm arguably has assumed the contractual risk of a market decline and should not be permitted to avoid the bargamed-for risk allocation because of a technical breach. The breach causes him no harm that he would not have suffered had the performance been conforming. It is unclear, however, whether any gain in commercial practice is realized by prohibiting the buyer from capitalizing on the seller's breach. To the extent that the parties previously had allocated risks between themselves, the seller had assumed the risk of failure to make a conforming delivery. Materialization of that risk should not be avoided any more readily than materialization of the risk of market decline. That the buyer receives a windfall from the fortuitous breacli does not necessarily mean that he is not entitled to it. There are numerous situations of acquisition through chance or good fortune in which the law will not intervene to alter the status quo. ${ }^{153}$

As an illustration, consider Powell's reference to the following example of the accepted application of the Frencli Civil Code provision that contracts be performed in good faith:

An importer sells a quantity of goods. A clause in the contract provides for 10 percent variation from the quantity because the importer wants to avoid liability for possible loss during importation or carriage. But lie cannot use the clause to increase or cut down by 10 percent the quantity he will deliver, according to whether there las been a rise or fall in the current price of the goods. That would be contrary to good faith. ${ }^{154}$

Assuming that the limited reason for the variation clause in the contract was not specified during negotiations nor by any usage of trade, it is unclear why the importer's taking advantage of a fortuitous market shift over which he exercised no control constitutes bad faith. Eitlier the importer or his buyer will receive a windfall from the changing narket. There is no way that both will obtain only the benefits assumed in the original contract. If the buyer had been concerned about such shifts, he presumably could have bargained expressly to limit use of the ten percent variation provision to actual losses suffered in transit. Even if one argues that the importer was in the best position to avoid

obligor can produce through his actions a superior state of affairs, this analysis indicates that good faith requires those actions be taken.

153. See Epstein, Possession as the Root of Title, 13 GA. L. REv. 1221, 1225 (1979).

154. Powell, supra note 2, at 30. 
the consequences of the changmg market, ${ }^{155}$ he hardly has earned the stigma associated with bad faith. Good faith should not be pressed into service to remake the parties' bargam. ${ }^{156}$

The poimt becomes clearer by positing that a commercial good saInaritan who "rescues" the seller in our first paradigm has a right to be compensated by the "rescuee" for loss suffered as a result of the rescue attempt. ${ }^{157}$ In the traditional rescue cases in tort law, acceptance of a restitutionary right does not affect our decision to encourage the rescue atteinpt. ${ }^{158}$ A requirement that a drowning person compensate his rescuer whose clothes are ruined in the rescue would presumably not lead the victim to resist rescue, as he still gains more than he loses after he has been saved and has provided restitution to the rescuer. In our first paradigm, ${ }^{159}$ however, a restitutionary right imdicates the futility of a rescue requirement. For example, if the buyer accepts the late delivery, thereby forgoing an opportunity to save himself $\$ 1000$ and preventimg the seller's potential $\$ 1000$ loss if the seller had been forced to resell the goods at the declined market price, the restitution argument suggests

155. See generally Posner \& Rosenfield, Impossibility and Related Doctrines in Contract Law: An Economic Analysis, 6 J. LEGAL STUd. 83 (1977); Speidel, Excusable Nonperformance in Sales Contracts: Some Thoughts About Risk Management, 54 S. C. L. Rev. 241 (1980).

156. Powell suggests other ways in which an expansive obligation of good faith may reduce certainty, such as by barring causes of action that are delayed but within the statute of limitations or by barring a statute of limitations defense although the time prescribed by the statute has run without the filing of the action. Powell, supra note 2, at 32. Powell also reports various abuses made of expansive good faith obligations under German law: "Under the Nazis . . [i]t became contrary to good faith . . . to adhere to contracts made with Jews or other anti-Nazis." Id. 35. There is no suggestion in this article that good faith provisions should be judged by sucls aberrational abuse.

Similar concerns for certainty of the legal positions of the parties led to rejection of an obligation of commercial good samaritanisin in Missouri Pub. Serv. Co. v. Peabody Coal Co., 583 S.W.2d 721 (Mo. Ct. App.), cert. denied, 444 U.S. 865 (1979). In that case the appellant, a supplier of coal, contended that the respondent purchaser of coal acted in bad faith in refusing to modify its contract to reflect increased inarket prices for coal. The court concluded:

Peabody's clarge is based entirely upon the refusal of Public Service to accede to Peabody's demands for price modification, which refusal, it asserts, constituted bad faith and thus placed the onns of breach upon Public Service. Neither the law of contracts generally nor the terms of U.C.C. relied upon by Peabody lend support to this theory. The contract here involved was settled as a result of arm's length dealing with no cloud of dishonesty, lack of good faith or failure to adhere to standard business or commercial practice upon the part of either party. . . . Where an enforceable, untainted contract exists, refusing inodification of price and seeking specific performance of valid covenants does not constitute bad faith or breach of contract, and the trial court properly so leeld. Id. at 725 .

157. Thanks are due to James Henderson for suggesting this argument.

158. Few cases recognize rights of restitution for rescuers. See, e.g., United States v. Consolidated Edison Co., 580 F.2d 1122 (2d Cir. 1978); Peninsular \& Oriental Steain Navigation Co. v. Overseas Oil Carriers, Inc., 553 F.2d 830 (2d Cir. 1977). Generally, volunteers are not entitled to claim restitution for their expenses. See II G. Palmer, LaW of Restrtution $\S 10$ (1978).

159. See text accompanying note 65 supra. 
that the buyer can recover his $\$ 1000$ from the seller. This result is absurd. The conduct of the buyer has not made any party better off; his conduct has merely transferred wealth that existed without his conduct. Nor does commercial practice or society appear to receive any gain.

One may, however, attempt to draw a negative inference from this argument and assert that when a commercial actor's conduct would leave another better off without making anyone, including himself, worse off, good faith requires altruistic conduct. The second paradigm $^{160}$ may be viewed as such an instance. Where the secured creditor is in possession of information not known to the debtor, revelation of that information would not simply allocate a loss, it would avoid the loss altogether. The creditor would retain his fully secured position while the debtor would be in the superior position of receiving full value for his collateral. In light of this argument, it is necessary to inquire whether an expansive good faith obhigation can be justified as a means of brimging about a superior state of affairs in these limited circumstances.

Theoretically, the good faith obligation should not be necessary in such a situation to move the parties to act in a manner that will facilitate the rescue. Assuming that the parties are in a position to bargain with one another over responsibility for conversion of the debentures, the debtor should be willing to enter into any bargain necessary to avoid the loss of the convertible feature's value so long as the cost to him is less than the loss that otherwise would be suffered. The creditor similarly should be willing to make the notification without any legal obligation, so long as he can recover costs incurred in the process. Nevertheless, creditors may fail to act for one of two reasons, neither of which would be eliminated by imposition of a good faith obligation. First, even if the actor-creditor is willing to conduct himself in a manner consistent with reaching an optimal state of affairs, that position may be indeterminate. Second, even if an objective actor can identify the optimal state of affairs, the actor-creditor nay be willing to forgo attainment of that position, despite the unnecessary cost his choice imposes on him.

1. Comparing States of Affairs-Indeterminacy. Indeterminacy of the optimal state of affairs exists if the creditor is uncertain whether he can recover his costs of notifying the debtor and thus cannot determine whether his post-notification status is favorable or equal to his pre-notification status. The parties' agreement inay be silent on the question of

160. See text accompanying notes 66-67 supra. 
restitution. Of course, once the creditor has obtained the information, the costs of notification should be minute, especially when compared to the potential loss to the debtor. Nevertheless, the creditor's reluctance to act in what appears to be the most rational ${ }^{161}$ manner may indicate that he values his freedom to refrain from such action more than the original calculus suggests. Imposition, through the good faith obligation, of a duty to notify may actually threaten the creditor's unspecified but more highly valued considerations. Such impositions may become disincentives to creditors to accept certain kinds of collateral that entail unwanted duties and thus impede cominercial transactions that concern such collateral. This result would be particularly undesirable if most creditors would have informed the debtor even in the absence of a requirement, notwithstanding costs to themselves. A creditor could act in this way out of altruism or a desire to obtain a competitive advantage over other creditors. That advantage, however, is lost once the notification becomes a requirement, and the creditor may eschew conduct that thus imposes only additional costs on him. ${ }^{162}$ Alternatively, a creditor may be willing to notify if the costs are small, but may avoid accepting the collateral altogether if notification is required. He may fear those few cases in which costs of notification become substantial, although still smaller than the benefits to the debtor of notification. ${ }^{163}$ The resulting restraimts on alienation of certain kinds of property could outweigh any gaims of a good faith obligation and thus produce a less than optimal state of affairs.

The indeterminacy issue may be even more apparent in response to the different, but related, argument that imposition of a good faith obhigation actually deters the creation of a superior state of affairs. In the following example, Professor Posner suggests that the modern theory of contract dainages-which views a contract as an undertaking to

161. Rawls's definition of "rational" behavior is followed here:

[A] rational person is thought to have a coherent set of preferences between the options open to him. He ranks these options according to how well they further his purposes; he follows the plan which will satisfy more of his desires rather than less, and which has the greater chance of being successfully executed. The special assumption I make is that a rational individual does not suffer from envy. He is not ready to accept a loss for himsclf if only others have less as well. He is not downcast by the knowledge or perception that others have a larger index of primary social goods. Or at least this is true as long as the differences between himself and others do not exceed certain himits, and he does not beheve that the existing inequalities are founded on injustice or are the result of letting chance work itself out for no compensating social purpose:

J. RAWLs, supra note 82, at 143.

162. See R. PosNer, supra note 126, at 132-33; Landes \& Posner, Salvors, Finders, Good Samaritans, and Other Rescuers: An Economic Study of Law and Altruism, 7 J. Legal Stud. 83 (1978).

163. See R. POSNER, supra note 126 , at 132. 
perform or pay damages for nonperformance ${ }^{164}$-properly avoids penalizing a breach that corrects a bargained-for misallocation of resources:

I sign a contract to deliver 100,000 custom-ground widgets at $\$ .10$ apiece to $\mathrm{A}$, for use in his boiler factory. After I have delivered $10,000, \mathrm{~B}$ comes to me, explains that lie desperately needs 25,000 custom-ground widgets at once since otherwise he will be forced to close his pianola factory at great cost, and offers ine $\$ .15$ apiece for 25,000 widgets. I sell him the widgets and as a result do not complete timely delivery to $\mathrm{A}$, who sustains $\$ 1000$ in lost profits from my breach. Having obtained an additional profit of $\$ 1250$ on the sale to B, I am better off even after reimbursing A for his loss. Society is also better off. Since B was willing to pay me $\$ .15$ per widget, it must mean that each widget was worth at least $\$ .15$ to him. But it was worth only $\$ .14$ to $A-$ the $\$ .10$ that he paid plus his expected profit of $\$ .04$ $(\$ 1,000$ divided by 25,000$)$. Thus the breach resulted in a transfer of the 25,000 widgets froin a less to a more valuable use. To be sure, had I refused to sell to $B$, he conld have gone to $A$ and negotiated an assignment of part of A's contract with me to him. But this would have introduced an additional step and so imposed additional transaction costs. 165

If we value allocative efficiency as an optimal state of affairs in contract remedies, Posner's hypothetical suggests we should not add damages that will deter the breach notwithstanding arguable bad faith conduct. ${ }^{166}$ Thus, we should not impose any additional remedy for

164. A classic statement of the theory that a contract is not a sacrosanct document to be honored in all its terms is found in Holmes, The Path of the Law, 10 HARv. L. REv. 457, 462 (1897):

Nowhere is the confusion betwecn legal and moral ideas inore manifest than in the law of contract. Among other things, here again the so called primary rights and duties are invested with a mystic significance beyond what can be assigned and explained. The duty to keep a contract at common law means a prediction that you must pay damages if you do not keep it, and nothing else. If you commit a tort, you are liable to pay a compensatory sum. If you commit a contract, you are liable to pay a compensatory sum unless the promised event comes to pass, and that is all the difference.

It might appear unclear why there is a conflict between efficiency in commercial law and an expansive notion of good faith that encourages commercial good sainaritanism. Rather, one might argue that the two notions are consistent. One of the traditional arguments against the common law's refnsal to recognize good samaritan duties in tort law is that if $\mathrm{A}$ can, at relatively small cost, avoid great harm to B, society at large will benefit. See Epstein, $A$ Theory of Strict Liability, $2 \mathrm{~J}$. LEGAL STUD. 151, 189-91 (1973). Similarly, one might argue that if a commercial actor can assist another at relatively low cost to himself, it would be efficient to require him to do so. In this instance an expansive interpretation of good faith would be consistent with the efficiency objective.

Liability for failure to rescue, lowever, may not be more efficient than nonliability. The costs of a liability rule may render it mefficient in its administration. See Landes \& Posner, supra note 162 , at 126.

165. R. POSNER, supra note 126, at 90.

166. The saine issue is presented, perhaps rhetorically, in E. FARNSWORTH \& W. YounG, Cases and Materials on Contracts 20 (1980). 
breach of the good faith obligation, at least if that remedy provides a disincentive to the efficient breach. ${ }^{167}$ Arguably, however, any such remedy is irrelevant to the promisor's conduct. In the absence of some remedy for bad faith, the promisor may attempt to keep $A$ from discovering the intention to breach out of a concern that $A$ may otherwise attempt to obtain a decree of specific performance. ${ }^{168}$ If $\mathrm{A}$ does not discover the imtention to breach, A will be limited to the lost profits recovery suggested by Posner, and the promisor will prosper. If, however, the promisor's hability might be imcreased by an independent recovery for bad faith, the promisor will be uncertain whether he will be better off breaching and paying all applicable damages or whether he should refram from breaching. If the promisor decides not to breach and forgoes opportunities to bargain with $\mathrm{A}$ about the situation, ${ }^{169}$ one might conclude that imposition of the good faith obligation actually lias deterred attainment of a superior state of affairs.

Indeterminacy of relative states of affairs, however, suggests that this conclusion is unwarranted. The conclusion proceeds from the assuniption that the aggrieved party, $\mathrm{A}$, has no reason to complain so long as he recovers the profit he expected on the transaction. ${ }^{170}$ If $\mathrm{A}$

167. For examples of efficient breach situations, see Jackson, "Anticipatory Repudiation" and the Temporal Element of Contract Law: An Economic Inquiry Into Contract Damages in Cases of Prospective Nonperformance, 31 StAN. L. Rev. 69, 86 n.59, 112 n.153 (1978).

168. See, e.g., Laclede Gas Co. v. Amoco Oil Co., 522 F.2d 33 (8th Cir. 1975); Kaiser Trading Co. v. Associated Metals \& Minerals Corp., 321 F. Supp. 923 (N.D. Cal. 1970). The propriety of granting specific performance in this situation is explored in Kronman, Specific Performance, 45 U. CHI. L. Rev. 351 (1978), and Schwartz, The Case for Specific Performance, 89 YALE L.J. 271 (1979).

169. There are other avenues open to the promisor, but they lead to the same result. For instance, if the promisor is uncertain whether he will be better off after breaching the contract and paying all damages, he may go to $A$ and inform him of his intention to breach. If $A$ protests that he cannot obtain the goods elsewhere, which is presumably true or else B would not value the goods so highly, the promisor may atteinpt to bargain out of the good faith penalty and propose to A that they sphit the $\$ .01$ per unit that the promisor expects to inake on the new contract. Assuming that the transaction costs of this additional bargain are low, the goods still will move into the hands of $B$, who values them most highly, while also increasing the benefits to the promisor and to A. Indeed, it might be argued that this is a superior result in that it makes beth the promisor and A bettcr off, rather than ouly the former, and prevents the promisor from benefiting by his broken promise to $A$ without sharing the gain with $A$.

For reasons described in the text, however, it is unlikely that A would agree to split the extra profit in this way. If he beheves or is uncertain that he was "made whole for his loss" with the original $\$ .04$, he is unlikely to be certain that he is in a position superior to that obtained by the promisor's performance if the promisor shares the extra $\$ .01$ with him. Thus, if the promisor fears that $A$ will attempt, on discovery of the intention to breach, to prevent the breach, e.g., by obtaining a decree of specifie performance, the promisor will not inform him of his intention to breach, will not try to reach any bargain with him, and will proceed as indicated in the text.

170. R. POSNER, supra note 126, at 89-90. 
were not, in fact, "inade whole for his loss"171 with the original \$.04 per widget recovery, the extent to which he is undercompensated may exceed the gains realized on the second contract. The sources of A's undercompensation are by now well rehearsed:172 inability to recover negotiation or litigation expenses imcurred to obtain traditional compensation, limitations on compensable damages to certain kinds of economic injuries, and limitations on measurement of those injuries to provable losses. ${ }^{173}$ For instance, if $\mathrm{A}$ had hoped that buyers of his goods that incorporated the widgets would contmue to deal with him, his failure to provide goods for them on this occasion may cost him profits on future unrelated transactions as well. Even with respect to those losses that are recoverable, idiosyncratic values placed on the contract by A may render performance nnore valuable to him than is indicated by objective compensation standards. ${ }^{174}$ For instance, he may place an idiosyncratic value on keeping promises to his customers. Because we cannot know whether undercompensation of the buyer exceeds gains realized by the seller on the second contract, we cannot conclude that the promisor's breach actually moves commercial practice to a superior state of affairs.

2. Comparing States of Affairs-Bad Guesses, Bad Motives. Even if we could identify one state of affairs as superior to another, it is not clear that imposition of a good faith obligation would lead to realization of the superior state. Insofar as good faith conduct requires actions that will produce a superior state of affairs, the obhgation is consistent with other consequentialist theories that seek to maximize the availability of certain goods. ${ }^{175}$ These theories present little internal difficulty 176 if we assume that an objective observer can identify, im a given set of circumstances, the 1nost desired consequences and the courses of conduct an actor should follow to obtain those consequences. If it were agreed that we should maximize the number of widgets in society and it were also agreed that pushing button A would produce 50 percent more widgets than pushing button $\mathrm{B}$, an objective observer would conclude that the actor should push button $\mathrm{A}$. The actor's actual knowledge or subjective behef about what he should do is

171. Id. 90.

172. See, e.g. Farnsworth, Legal Remedies for Breach of Contract, 70 ColuM. L. Rev. 1145, 1216 (1970); Goetz \& Scoth, supra note 143, at 558 n.19.

173. See Goetz \& Scott, supra note 143, at $558 \mathrm{n} .19$ and citations therein.

174. See Williams, supra note $107,79,82-85$.

175. See id. 82-93.

176. That is to say, these theories are comprehensible and logical, although not necessarily correct from a normative standpoint. 
immaterial to the correctness of his conduct; if, however, he misperceives facts or lacks knowledge, his conduct is unlikely to achieve the state of affairs that he seeks. ${ }^{177}$ If the actor, in his well-intentioned folly, believes that he can produce inore widgets by pushing button B, he will push that button and thereby fail to attain an optimal state of affairs. Nevertheless, a consequentialist theory that defines "right action" in non-objective terms will approve his conduct. It is, therefore, important to realize the subjective nature of the obligation of good faith. ${ }^{178}$ The actor who is informed that good faith requires him to act in a manner that inaximizes the welfare of all concerned may misperceive the positions of the various parties and, in particular, is likely to overestimate the beneficial consequences to others of action that benefits himself.

For instance, in Posner's example the prospective breacher stands to gam from nonperformance of the first contract. Even if he is informed that he should avoid his contract and pay damagcs only if society benefits from such conduct, he cannot act objectively in deciding whether to breach the contract. Inevitably influenced by the prospect of his own gam, he may overvalue the beneficial consequences to others of his breach, ignore the aggrieved party's undercompensation and therefore fail to perform the contract even though his breach does not achieve a superior state of affairs. Similarly, the buyer in our first paradigm may view his savings if he avoids his bad bargain as indicative of society's savings as well and thus find a breach where none exists. In neither case, however, can we say that the breacher has failed to act in good faith. The subjective standard for good faith conduct prohibits labeling as bad faith conduct that is only misguided or foohsh if that conduct is consistent with the actor's beliefs about his obligation or his beliefs about the facts that determine his obligation. ${ }^{179}$ Thus, good faith conduct will not nccessarily produce a superior state of affairs.

It might be possible to reconcile a subjective definition of good faith with a desire to make good faitl consistent with welfare-maximizing conduct if actors had mcentives to scrutinize carefully the consequences of their conduct and thereby to increase the probability of making guesses that actually reflect welfare-maximizing conduct. The incentives might temper the tendency of commercial actors to inake

177. Cf. D. Regan, Utilitarianism AND Cooperation 12-13 (1980) (discusses the difference between "subjective probabilities" and "true probabilities" in the context of "act-utilitarianism").

178. See text accompanying note 108 supra.

179. See, e.g., Industrial Nat'1 Bank v. Leo's Used Car Exch., 362 Mass. 797, 291 N.E.2d 603 (1973). 
guesses about welfare-maximizing choices based on self-interest. The risk of overvaluation of prospective personal loss has led to a rule in tort law that requires one who damages property of another im order to save his own property to compensate the other party for the damage done. ${ }^{180}$ The rule is intended to provide an incentive to save from injury more highly valued goods. Thus, if the endangered party guesses wrong about the relative value of his goods, he will be penalized to the extent that the other property was more valuable. In contract law, however, there is no disincentive to breach where society would be better off with performance because of the undercompensation inherent in the damage system and the failure to take froin the breacher the gains of his breach. ${ }^{181}$ If the deliberate breacher guesses correctly about the relative value of the new contract he can make, he arguably benefits both himself and society, as suggested by Posner in the above example. ${ }^{182}$ Even if the new contract turns out not to create a superior state of affairs, however, the breacher will not have to divest any gains from his new contract after compensating the aggrieved party for tlie breach. Thus, the potential deliberate breacher has nothing to lose by his breach and has a possibility of gain. His actions are in good faith if he engages in self-interested conduct consistent with his perceptions of welfare-maximizing conduct.

Finally, if a model of rational beliavior ${ }^{183}$ indicates that a commercial actor would attempt, albeit unsuccessfully, to attain an optimal state of affairs even without imposition of a good faith obligation, the fact that the actor conducts himself otherwise simply may suggest that he is not acting rationally. Failure to assist others may evolve not ouly from mistake, as suggested above, but also from spite or envy. ${ }^{184}$ Even with all the information and capability necessary to bring about the optimal state of affairs, the ungenerous actor simply may desire not to help someone else, especially if the actor's ex post situation is the same as his $e x$ ante situation, i.e., there is reimbursement for costs incurred by the rescuer, but no reward or profit for his conduct. Indeed, the actor even may be willing to accept certain costs to realize irrational, or at least unkind, objectives. Even if such motivations are not considered in calculating the highest-valued alternative for purposes of defining

180. See Vincent v. Lake Erie Transp. Co., 109 Minn. 456, 124 N.W. 221 (1910). The incentive value of the rule is explored in Gillette, supra note 70, at 388-92.

181. See Farnsworth, supra note 172.

182. See R. POSNER, supra note 126 , at 90 .

183. See note 161 supra.

184. See Leff, supra note 64 . 
good faith conduct, ${ }^{185}$ it is possible that imposition of some cost for violation of the good faith obligation would not deter the envious or spiteful person. To the extent that commercial actors conduct themselves irrationally, the good faitlı obligation will not produce a superior state of affairs.

\section{CONCLUSION}

It may be superficially imconsistent to commend the Code's good faith provision as a means to imbue commercial transactions with a moral overlay and to refuse to define those provisions broadly. Notlimg in this article, however, is intended to disparage adherence by commercial actors to the broadest possible interpretation of good faith. The concern in this article is that attempts to enforce such an interpretation through the legal system must confront costly obstacles precipitated by the limitations of that system. These limitations may be irrelevant to the inherent worth of good faith. ${ }^{186}$ To the extent they are irrelevant, the question is whether there is some way to attain the value of a broad good faitl obligation while avoiding its limitations.

It may be that the mere presence of a good faith obligation goes far in this direction. The precatory use of the good faitl provision has been demeaned, ${ }^{187}$ but this criticism is shortsiglited. Even if good faith receives a narrow judicial interpretation, it may induce desirable commercial conduct in marginal areas. Moreover, the statement of a good faith obligation, even narrowly construed for purposes of liability, effectively may convey the impression that commercial benevolence constitutes a supererogatory act that commercial actors should pursue, notwithstandimg the legal system's neutrality on the issue. That, of course, has been our attitude toward actors who have the opportunity to prevent physical harm to others at minimal cost to themselves. Our unwillingness to impose sanctions on the actor who fails to attempt rescue does not suggest we are indifferent to his conduct. Rather the legal response recognizes difficulties inherent in the attempt to enforce a contrary rule. There may be distmctions between the nonrescuers of tort law and commercial actors who fail to extricate others from misfortune that suggest a need or willingness to extend liability to the latter. For

185. See Williams, supra note 107, 104-05 (presenting the argument that a strict utilitarian should give no weight to "bad feelings" in calculating the proper course of action).

186. See J. RAWLS, supra note 82, at 176 :

[W] hen we enter an agreeinent we must be able to lonor it even should the worse possibilities prove to be the case. Otherwise we have not acted in good faith. Thus the parties must weigh with care whether they will be able to stick by their commitment in all circumstances.

187. See Dugan, supra note 2, at 47. 
instance, the commercial actor not only fails to rescue in numerous cases, but also directly benefits from the other's misfortune and thus needs soine countervailing imcentive to act benevolently. Furthermore, contract and commercial law already deviate from noninterventiomism by virtue of doctrines such as mitigation and by damage formulae intended to prevent nonbreachers from reaping windfalls. The point of the article is not the wrongheadedness of atteinpts to conform commercial conduct to ethical or economic objectives. Rather, the intent is to raise questions about using notions of good faith for that purpose. Since most of the difficulties that generate the questions lie in the administration and remedy of a good faith obligation, one might hope to capture the benefits of an expansive obligation while avoidmg the obstacles. If so, the best course is one that administers the less troublesome narrow conception of good faith with an ancillary exhortative or precatory function that carries no legal sanctions. Beyond moral suasion, however, enforcement of an expansive notion of good faith appears to present overwhelming difficulties. 
